\title{
A Multidirectional Perspective for Novel Functional Products: In vitro Pharmacological Activities and In silico Studies on Ononis natrix subsp. hispanica
}

\author{
Serife Yerlikaya ${ }^{1 *}$, Gokhan Zengin ${ }^{2 *}$, Adriano Mollica ${ }^{3}$, Mehmet C. Baloglu ${ }^{1}$, \\ Yasemin Celik Altunoglu ${ }^{1}$ and Abdurrahman Aktumsek ${ }^{2}$ \\ ${ }^{1}$ Department of Genetics and Bioengineering, Faculty of Engineering and Architecture, Kastamonu University, Kastamonu, \\ Turkey, ${ }^{2}$ Department of Biology, Science Faculty, Selcuk University, Konya, Turkey, ${ }^{3}$ Department of Pharmacy University \\ "G. d'Annunzio" of Chieti-Pescara, Chieti, Italy
}

OPEN ACCESS

Edited by:

Atanas G. Atanasov, Institute of Genetics and Animal

Breeding (PAN), Poland

Reviewed by:

M. Babak Bahadori,

Tabriz University of Medical Sciences,

Kannan R. R. Rengasamy, China Agricultural University, China

*Correspondence: Serife Yerlikaya serifeyerlikaya@gmail.com Gokhan Zengin

gokhanzengin@selcuk.edu.tr

Specialty section

This article was submitted to

Ethnopharmacology,

a section of the journal

Frontiers in Pharmacology

Received: 08 July 2017

Accepted: 21 August 2017 Published: 01 September 2017

Citation:

Yerlikaya S, Zengin G, Mollica A, Baloglu MC, Celik Altunoglu Y and Aktumsek A (2017) A Multidirectional

Perspective for Novel Functional

Products: In vitro Pharmacological Activities and In silico Studies on Ononis natrix subsp. hispanica.

Front. Pharmacol. 8:600. doi: 10.3389/fphar.2017.00600
The genus Ononis has important value as traditional drugs and foods. In the present work, we aimed to assess the chemical profiles and biological effects of Ononis natrix subsp. hispanica extracts (ethyl acetate, methanol, and water). For chemical profile, total and individual phenolic components were detected. For biological effects, antioxidant (DPPH, ABTS, CUPRAC, FRAP, phosphomolybdenum, and metal chelating assays), enzyme inhibitory (against cholinesterase, tyrosinase, $\alpha$-amylase and $\alpha$-glucosidase), antimicrobial, DNA protection and cytotoxic abilities were tested. The predominant phenolics were apigenin, luteolin, and quercetin in the tested extracts. Generally, the ethyl acetate and methanol extracts were noted as the most active in the antioxidant and enzyme inhibitory assays. Water extract with different concentrations indicated high level of DNA protection activity. Methanol and ethyl acetate extracts showed antibacterial effect against to Staphylococcus aureus and Staphylococcus epidermidis strains. The cytotoxic effects of $O$. natrix subsp. hispanica extracts on the survival of HeLa and PC3 cells were determined by MTT cell viability assay. Water and methanol extracts caused initiation of apoptosis for PC3 cell line. Furthermore, molecular docking was performed to better understand interactions between dominant phenolic compounds and selected enzymes. Our results clearly indicate that $O$. natrix subsp. hispanica could be considered a potential candidate for designing novel pharmaceuticals, cosmeceuticals and nutraceuticals.

Keywords: Ononis, bioactive compounds, natural agents, pharmaceuticals, molecular docking

\section{INTRODUCTION}

In the twenty first century, the usage of plant or plant products are undergoing a revolution as sources of prominent (functional and bioactive) compounds. For example, artemisinin was awarded as an anti-malarial compound in Nobel Prize for Medicine 2015 (Omura and Campbell, 2015). From this point, to better combat the lifestyle, communicable or infectious diseases, many phytochemicals have been suggested as antioxidant, antimicrobial, anticancer 
and anti-mutagenic agents (Fernandes et al., 2017; LosadaBarreiro and Bravo-Díaz, 2017; Meeran et al., 2017; Yin et al., 2017). These facts provide encouragement for designing further studies on the plants. Within these perspectives, the term of functional products has emerged and it is defined as any products which provide health benefits including treatment of afore-mentioned diseases. In this framework, uninvestigated wild plants could be considered as a springboard for designing novel functional products with low toxicity.

The genus Ononis (Fabaceae) is represented by 75 species in the world especially Europe and Central Asia (Wollenweber et al., 2003). The genus comprises of 23 taxa in Tukey and known as "semisk" and "kayışkıran" in Turkish name (Baytop, 1999; Sohretoglu, 2007; Mükemre et al., 2015). In the literature, several studies were reported that member of the genus Ononis exhibited significant biological activities, such as antimicrobial effect (Mhamdi et al., 2015; Sayari et al., 2016), antioxidant (Mhamdi et al., 2015; Mezrag et al., 2017), wound healing (Süntar et al., 2011), cytotoxic (Kuete et al., 2013; Ghribi et al., 2016), and analgesic (Yõlmaz et al., 2006). In addition, the decoctions from Ononis species is used for treating urinary problems, skin disorders as well as gout (Baytop, 1999; Erdemgil et al., 2002; Liebezeit, 2008). With this in mind, Ononis species have been sold as herbal tea on the market as single or combined with other diuretic plants (Gampe et al., 2016). Several publications have appeared in recent years documenting on biological activities of some Ononis species along with their phytochemicals profiles (Daruházi et al., 2008; Al-Rehaily et al., 2014; Ghribi et al., 2015; Yousaf et al., 2015; Gampe et al., 2016; Casiglia et al., 2017; Mezrag et al., 2017). However, to the best of our knowledge, there is no report on the chemical profile and biological ability of Ononis natrix subsp. hispanica. Thus, the present study aims to provide more details about chemical and biological properties of $O$. natrix subsp. hispanica. The observed findings could be provide new insights for $O$. natrix subsp. hispanica.

\section{MATERIALS AND METHODS}

\section{Plant Material and Preparation of the Extracts}

Ononis natrix subsp. hispanica was collected from AntalyaTurkey during of flowering season (June 2015). Taxonomic identification of the plant material was confirmed by the senior taxonomist Dr. Murad Aydin Sanda, from the Department of Biology, Selcuk University. The voucher specimen has been deposited at the Herbarium of the Department of Biology, Selcuk University, Konya-Turkey.

To obtain ethyl acetate and methanol extracts, the air-dried aerial parts $(10 \mathrm{~g})$ were macerated with $200 \mathrm{~mL}$ of these solvents at room temperature $\left(25^{\circ} \pm 1^{\circ} \mathrm{C}\right)$ for $24 \mathrm{~h}$. The extracts were concentrated under vacuum at $40^{\circ} \mathrm{C}$ by using a rotary evaporator. To obtain water extract, the powdered samples were boiled with $250 \mathrm{~mL}$ of distilled water for $30 \mathrm{~min}$. The aqueous extract was filtered, lyophilized $\left(-80^{\circ} \mathrm{C}, 48 \mathrm{~h}\right)$, and all extracts stored at + $4^{\circ} \mathrm{C}$ in the dark until use.

\section{Total Phenolics, Flavonoids, and Phenolic Composition}

The total phenolics content was determined by Folin-Ciocalteu method (Slinkard and Singleton, 1977) with slight modification and expressed as gallic acid equivalents (GAE/g extract), while total flavonoids content was determined using $\mathrm{AlCl}_{3}$ method (Zengin et al., 2014) with slight modification and expressed as rutin equivalents (RE/g extract).

Phenolic compounds were evaluated by RP-HPLC (Shimadzu Scientific Instruments, Tokyo, Japan). Detection and quantification were carried out with a LC-10ADvp pump, a Diode Array Detector, a CTO-10Avp column heater, SCL-10Avp system controller, DGU-14A degasser and SIL-10ADvp auto sampler (Shimadzu Scientific Instruments, Columbia, MD). Separations were conducted at $30^{\circ} \mathrm{C}$ on Agilent ${ }^{\circledR}$ Eclipse XDB C-18 reversed-phase column $(250 \times 4.6 \mathrm{~mm}$ length, 5 $\mu \mathrm{m}$ particle size). Phenolic compositions of the extracts were determined by a modified method of Zengin et al. (2014). Gallic acid, protocatechuic acid, (+)-catechin, p-hydroxybenzoic acid, chlorogenic acid, caffeic acid, (-)-epicatechin, syringic acid, vanillin, $p$-coumaric acid, ferulic acid, sinapic acid, benzoic acid, $o$-coumaric acid, rutin, hesperidin, rosmarinic acid, eriodictyol, trans-cinnamic acid, quercetin, luteolin, kaempferol, and apigenin were used as standards. Identification and quantitative analysis were done by comparison with standards. The amount of each phenolic compound was expressed as microgram per gram of extract using external calibration curves, which were obtained for each phenolic standard.

\section{Antioxidant and Enzyme Inhibitory Assays}

Antioxidant [DPPH, ABTS radical scavenging, reducing power (CUPRAC and FRAP), phosphomolybdenum and metal chelating (ferrozine method) and enzyme inhibitory assays (cholinesterase (Elmann's method), tyrosinase (dopachrome method), $\alpha$-amylase (iodine/potassium iodide method) and $\alpha$-glucosidase (chromogenic PNPG method)] were performed according to our previous researches (Zengin et al., 2014; Zengin, 2016). Antioxidant capacities were expressed as equivalents of trolox and EDTA (for metal chelating). In addition, the enzyme inhibitory activities of the extracts were evaluated as equivalents of standard inhibitors per gram of the plant extract (galantamine for AChE and BChE, kojic acid for tyrosinase, and acarbose for $\alpha$-amylase and $\alpha$-glucosidase inhibition assays).

\section{Molecular Modelling}

\section{Receptors Preparation}

The crystalline structure of the selected enzymes together with their inhibitors have been downloaded from the Protein Databank RCSB PDB (Berman et al., 2000): acetylcholinesterase (pdb:4X3C) (Pesaresi and Lamba, in press) in complex with tacrine-nicotinamide hybrid inhibitor, butyrilcholinesterase (pdb:4BDS) (Nachon et al., 2013) in complex with tacrine, amylase (pdb:1VAH) (Zhuo et al., 2004) in complex with rnitrophenyl- $\alpha$-D-maltoside, glucosidase (pdb:3AXI) (Yamamoto et al., 2011) in complex with maltose and tyrosinase (pdb:2Y9X) (Ismaya et al., 2011) in complex with tropolone. The raw crystal structures were prepared for the docking experiments as 
previously reported (Mocan et al., 2016; Uysal et al., 2016). Noncatalytic water molecules, inhibitors and all the other molecules present in the pdb files were removed by using UCSF Chimera (DeLano, 2002) and the proteins alone were neutralized at $\mathrm{pH}$ 7.4 by PropKa implemented in Maestro 10.2 suite (Maestro, 2015). Seleno-cysteines and seleno-methionines, if present, were converted to cysteines and methionines, respectively. All the missing fragments and other errors present in the crystal structures were automatically solved by the Wizard Protein Preparation implemented in Maestro 10.2 suite (Maestro, 2015).

\section{Ligands Preparation}

$(+)$-Epicatechin, apigenin, luteolin, quercetin and rosmarinic acid were selected as representative compounds to carry out molecular docking study, as these compounds were present in abundance in the herbs extracts. The chemical structure the selected compounds are reported in Figure 1. The three dimensional structures have been downloaded from Zinc databases (Irwin et al., 2012) and used for molecular modeling experiments after preparation. The ligands were prepared by the LigPrep tool embedded in Maestro 10.2, neutralized at $\mathrm{pH} 7.4$ by Ionizer and minimized by OPLS3 force field (Shelley et al., 2007).

\section{Molecular Docking}

Dockings of the representative substances have been performed for each selected enzyme employed for the in vitro enzymatic inhibition tests in this work. Glide embedded in the maestro suite 10.2 has been employed for the docking calculations by using the "eXtra Precision" scoring function for all the enzymes and the mm-GBSA binding energy has been calculated by the use of Prime embedded in maestro 10.2 (Table 1; Jones et al., 1997). In all cases, the binding pocket was determined automatically by centering the grid on the crystallographic inhibitor, extended in a radius of 10 Angstroms from the center. The best pose for each compound docked to the selected enzymes was the best ranked among the 10,000 generated.

\section{DNA Protection}

DNA protection activity of the studied extracts was analyzed using pUC19 plasmid DNA (pDNA). Plasmid isolation was performed by Thermo Scientific Genejet Plasmid Miniprep Kit. The reaction mixture contained $5 \mu \mathrm{L}$ of Fenton's reagent $(30 \mathrm{mM}$ $\mathrm{H}_{2} \mathrm{O}_{2}, 50 \mathrm{mM}$ ascorbic acid, and $\left.80 \mathrm{mM} \mathrm{FeCI}_{3}\right), 5 \mu \mathrm{L}$ of these extracts at two different concentrations $(5$ and $10 \mathrm{mg} / \mathrm{mL}$ ) and $3 \mu \mathrm{L}$ of pDNA $(300 \mu \mathrm{g} / \mu \mathrm{L})$. Final volume of reaction mixture was brought up to $20 \mu \mathrm{L}$ using double-distilled water. Positive control was composed of $12 \mu \mathrm{L}$ of distilled water, $5 \mu \mathrm{L}$ of Fenton's reagent and $3 \mu \mathrm{L}$ of pDNA. Negative control involved only $17 \mu \mathrm{L}$ of distilled water and $3 \mu \mathrm{L}$ of pDNA. Samples were incubated for $30 \mathrm{~min}$ at $37^{\circ} \mathrm{C}$ and $4 \mu \mathrm{L}$ loading dye (Thermo Scientific, USA) was added to the all mixtures. The DNA mixtures were run on $0.8 \%$ agarose gel and then visualized under ultraviolet light cabin. Biological replication of test was carried out at three times and band density was determined by the gel image analysis software (Quantum, Vision-Capt., Vilber Lourmat SAS, France) (Ozkan et al., 2015).

\section{Cytotoxic Evaluation}

\section{Cell Culture Materials}

HeLa and PC3 cancer cell lines were obtained from Selcuk University, Faculty of Science, and Department of Biochemistry. Penicillin/Streptomycin, EMEM cell culture media, Ham's F12 cell culture media, Fetal bovine serum (FBS), trypsin, MTT, ethanol, 2-prophanol, $60 \times 15 \mathrm{~mm}$ corning plates and $75 \mathrm{~cm}^{2}$<smiles>O=c1cc(-c2ccc(O)cc2)oc2cc(O)cc(O)c12</smiles><smiles>O=c1cc(-c2cc(O)cc(O)c2)oc2cc(O)cc(O)c12</smiles><smiles>O=c1c(O)c(-c2ccc(O)c(O)c2)oc2cc(O)cc(O)c12</smiles>

FIGURE 1 | Chemical structure of apigenin, luteolin and quercetin.

TABLE 1 | Binding energy and glide XP docking scores.

\begin{tabular}{|c|c|c|c|c|c|c|c|c|c|c|}
\hline \multirow[t]{2}{*}{ Compounds } & \multicolumn{2}{|c|}{$\mathrm{AChE}^{\star}$} & \multicolumn{2}{|c|}{ BChE* } & \multicolumn{2}{|c|}{$\alpha$-amylase* } & \multicolumn{2}{|c|}{$\alpha$-glucosidase* } & \multicolumn{2}{|c|}{ Tyrosinase* } \\
\hline & $\mathbf{X P}$ & $\Delta \mathbf{G}$ & $\mathbf{X P}$ & $\Delta \mathbf{G}$ & $\mathbf{X P}$ & $\Delta \mathbf{G}$ & $\mathbf{X P}$ & $\Delta \mathbf{G}$ & $\mathbf{X P}$ & $\Delta \mathbf{G}$ \\
\hline Apigenin & -9.6 & -60.6 & -9.4 & -52.5 & -5.98 & -35.2 & -5.7 & -17.2 & -5.7 & -26.1 \\
\hline Benzoic A. & -4.0 & -14.2 & -4.9 & -22.3 & -3.88 & -0.03 & -2.3 & +71.8 & -5.1 & +41.7 \\
\hline (-)-Epicat. & -9.3 & -41.5 & -7.3 & -41.0 & -7.03 & -38.1 & -6.9 & -21.8 & -5.5 & -20.9 \\
\hline Luteolin & -9.6 & -52.9 & -8.0 & -53.3 & -6.54 & -54.0 & -6.7 & -30.3 & -5.1 & -29.3 \\
\hline Quercetin & -10.3 & -62.9 & -7.9 & -43.5 & -8.79 & -52.9 & -6.9 & -31.2 & -5.4 & -28.3 \\
\hline Rosmarinic A. & -11.3 & -64.5 & -10.9 & -42.8 & -8.26 & -46.8 & -6.5 & -22.6 & -6.3 & -12.2 \\
\hline
\end{tabular}

${ }^{*} \Delta G$ values (Binding energy) are expressed in $\mathrm{Kcal} / \mathrm{mol}$. 
corning flasks were purchased from Sigma-Aldrich (SigmaAldrich, USA).

\section{Cell Culture Maintenance}

Culture media were prepared with 10\% fetal bovine serum (FBS) and $1 \%$ penicillin-streptomycin (Pen-Strep) solution. Prepared medium was kept at $+4^{\circ} \mathrm{C}$ and warmed at $37^{\circ} \mathrm{C}$ before using. Cells (HeLa, PC3) were proliferated in incubator $\left(37^{\circ} \mathrm{C}\right.$ including $5 \% \mathrm{CO}_{2}$ ). Stock cells were proliferated in $75 \mathrm{~cm}^{2}$ sterile corning flasks and experiment cell cultures were proliferated in $60 \times 15$ $\mathrm{mm}$ sterile petri dishes. In the logarithmic phase of the growth (when reached to $\sim 80 \%$ cell confluency), cells were sub-cultured (Karakurt and Adali, 2016).

\section{Preparation of Plant Extraction}

Dilutions were made to obtain extract concentration of $10 \mathrm{mg} / \mathrm{ml}$. The water extract was suspended in PBS and other extracts were suspended in DMSO (Dimethylsulfoxide)/water (1:5) and the diluted extracts were centrifuged at 10,000 $\times$ g during $2 \mathrm{~min}$, and supernatants were filtrated (having the diameter of $0.22 \mu \mathrm{m}$ pore size) and they were kept in $-20^{\circ} \mathrm{C}$.

\section{MTT Cell Viability Test}

A total of 10.000 PC3 and HeLa cells were seeded in 96-well plates and allowed to fasten on the wells for $24 \mathrm{~h}$. After $24 \mathrm{~h}$, cells were treated with different doses of the tested extracts $(0.1$, $1,2.5,5$, and $10 \mathrm{mg}$ for water) $(0.1,1,10,100$, and $1,000 \mu \mathrm{g}$ for ethyl acetate and methanol) for $24 \mathrm{~h}$. After exposure time completed, the medium was changed with EMEM and Ham's F12 medium supplemented with $0.5 \%$ FBS $+0.5 \mathrm{mg} / \mathrm{ml} \mathrm{MTT}$ for HeLa and PC3 cancer cells, respectively. Then, they were incubated at $37^{\circ} \mathrm{C}$ with $5 \% \mathrm{CO}_{2}$, for $4 \mathrm{~h}$. After that time, the cells were treated with $3 \% \mathrm{SDS}+40 \mathrm{mM} \mathrm{HCl} /$ isopropanol for $15 \mathrm{~min}$ in order to dissolve the MTT-formazan crystals (Yerlikaya et al., 2016). The absorbance of each sample was recorded at $570 \mathrm{~nm}$. Cell survival rate was calculated by using GraphPad Prism 3.03 software (GraphPad Software, Inc., La Jolla, CA, USA).

\section{Antimicrobial Activity}

Antimicrobial activity test was performed by disc diffusion method. Nutrient agar medium was used for test microorganisms and microorganisms were refreshed in $100 \mathrm{~mm}$ sterile petri dishes. Single colony of bacterial strain was inoculated in $20 \mathrm{ml}$ nutrient broth medium for $24 \mathrm{~h}$ at $37^{\circ} \mathrm{C}$ incubator. After bacteria concentration was made visible in \%9 sterile $\mathrm{NaCI}$ and its turbidity was standardized to $0.5 \mathrm{McF}$ arland by adding bacterial suspension. Bacterial suspension seeded to $100 \mathrm{~mm}$ petri dishes. After the tested extracts were dissolved in DMSO and saturated on discs, they were incubated at room temperature for drying. They were placed on the inoculated petri plates with microorganisms for $24 \mathrm{~h}$ at $37^{\circ} \mathrm{C}$ incubator. Test was replicated at least three times and results were analyzed by measuring inhibition zone. Microorganisms were illustrated on Table 2.

\section{Statistical Analysis}

All the assays were carried out in triplicate. The results were expressed as mean value and standard deviation (mean \pm
TABLE 2 | Microorganisms used for antimicrobial activity test.

\begin{tabular}{lcc}
\hline Microorganisms & Gram (+) & Gram (-) \\
\hline Klebsiella pneumonia & & $x$ \\
Staphylococcus aureus ATCC 25923 & $x$ & \\
Staphylococcus hominis & $x$ & $x$ \\
Proteus vulgaris & & $X$ \\
Escherichia coli & & $x$ \\
Serratia marcescens & $x$ & \\
Staphylococcus epidermidis & $x$ & \\
Alfa streptococcus haemolyticua & $x$ & \\
Enterococcus faecium & & \\
Pseudomonas aeruginosa & $x$ & \\
Listeria monocytogenes ATCC 7644 & $x$ & $x$ \\
Enterococcus durans & & \\
Salmonella kentucky & & \\
Enterobacter aerogenes ATCC 13048 & & \\
\hline
\end{tabular}

SD). Statistical differences between the extracts were analyzed by using one-way analysis of variance (ANOVA) followed by Tukey's honestly significant difference post-hoc test $(\alpha=$ 0.05). All the analysis was carried out using SPSS v22.0 software.

\section{RESULTS AND DISCUSSION \\ Phytochemical Composition}

In the last decades, many studies highlighted biological activities of phenolic compounds, such as antioxidant, anticancer, antimicrobial, and anti-inflammatory. Flavonoids are the most abundant group of phenolics and considered as natural bioactive agents for designing novel functional products. In this sense, the amounts of total phenolics and flavonoids contents in $O$. natrix extracts were determined by Folin-Ciocalteu and $\mathrm{AlCl}_{3}$ methods. The greatest content of total phenolics was noticed in the ethyl acetate extract (60.19 mgGAE/g extract), followed by methanol (59.22 mgGAE/g extract) and water (35.12 mgGAE/g extract) extracts. Similar results were observed for flavonoid as well (Table 3). These findings were confirmed by several researchers who reported the higher concentration of total phenolics in ethyl acetate and methanol extracts (Do et al., 2014; Murugan and Parimelazhagan, 2014). In a previous study (Mhamdi et al., 2015), the total phenolic content of O. natrix in Tunisia was reported as $51 \mathrm{mgGAE} / \mathrm{g}$, which was lower than that found in the present study. Moreover, some researchers were found to be different levels of total phenolics in several Ononis species, such as O. spinosa (3.09 mgGAE/g extract) (Orhan et al., 2012), O. pubescens (17.23 mgGAE/g extract), and O. ornithopodioides (20.96 mgGAE/g extract) (Sarikürkcü et al., 2016).

Individual phenolic constituents in the tested extracts were analyzed by HPLC-DAD and the results are given in Table 4. A total of 23 standard phenolics were used and 21 of them were identified in these extracts. Two compounds (rutin and hesperidin) were not detected in the extracts. Apigenin was 
TABLE 3 | Total phenolic and flavonoid contents, and free radical scavenging (DPPH and ABTS) activities of the extracts.

\begin{tabular}{|c|c|c|c|c|}
\hline Extracts & Total phenolic content (mgGAE/g extract) & Total flavonoid content (mgRE/g extract) & DPPH (mgTE/g extract) & ABTS (mgTE/g extract) \\
\hline Ethyl acetate & $60.19 \pm 1.67^{\star}$ & $30.07 \pm 0.39$ & $56.60 \pm 1.46$ & $530.37 \pm 0.40$ \\
\hline Methanol & $59.22 \pm 0.09$ & $28.40 \pm 0.27$ & $63.95 \pm 1.45$ & $521.80 \pm 2.90$ \\
\hline Water & $35.12 \pm 0.07$ & $10.25 \pm 0.23$ & $63.38 \pm 1.10$ & $457.92 \pm 2.29$ \\
\hline
\end{tabular}

GAE, gallic acid equivalents; RE, rutin equivalents; TE, trolox equivalents.

*Values expressed are means \pm S.D. of three parallel measurements.

TABLE 4 | Quantitative analysis for determination of phenolic components in the extracts ( $\mu \mathrm{g} / \mathrm{g}$ extract).

\begin{tabular}{|c|c|c|c|c|c|c|c|c|}
\hline \multirow[t]{2}{*}{ No. } & \multirow[t]{2}{*}{ Phenolic compounds } & \multicolumn{3}{|c|}{ Extracts } & \multicolumn{4}{|c|}{ Analytical characteristics } \\
\hline & & Ethyl acetate & Methanol & Water & Linear range (ppm) & $r^{2}$ & LOD (ppm) & LOQ (ppm) \\
\hline 1 & Gallic acid & $8 \pm 0.4$ & $100 \pm 0.8$ & $58 \pm 0.8$ & $0.20-25.0$ & 0.9993 & 0.075 & 0.227 \\
\hline 2 & Protocatechuic acid & $10 \pm 0.4$ & $80 \pm 0.6$ & $234 \pm 8$ & $0.20-25.0$ & 0.9991 & 0.086 & 0.260 \\
\hline 3 & $(+)$-Catechin & nd & $152 \pm 2$ & $492 \pm 20$ & $0.90-113$ & 0.9988 & 0.172 & 0.522 \\
\hline 4 & $p$-Hydroxybenzoic acid & $44 \pm 4$ & $106 \pm 4$ & $200 \pm 4$ & $0.20-25.0$ & 0.9994 & 0.007 & 0.020 \\
\hline 5 & Chlorogenic acid & $210 \pm 2$ & nd & $166 \pm 2$ & $0.35-45.0$ & 0.9988 & 0.080 & 0.241 \\
\hline 6 & Caffeic acid & $42 \pm 4$ & $34 \pm 4$ & $90 \pm 4$ & $0.16-21.0$ & 0.9993 & 0.054 & 0.162 \\
\hline 7 & (-)-Epicatechin & $310 \pm 16$ & $950 \pm 24$ & nd & $0.50-66.0$ & 0.9990 & 0.170 & 0.514 \\
\hline 8 & Syringic acid & $22 \pm 0.2$ & $66 \pm 4$ & $86 \pm 4$ & $0.05-12.0$ & 0.9995 & 0.030 & 0.090 \\
\hline 9 & Vanillin & $2 \pm 0.1$ & $10 \pm 0.2$ & nd & $0.08-10.0$ & 0.9995 & 0.020 & 0.060 \\
\hline 10 & $p$-coumaric acid & $8 \pm 0.6$ & $34 \pm 2$ & $64 \pm 2$ & $0.04-6.0$ & 0.9996 & 0.066 & 0.199 \\
\hline 11 & Ferulic acid & $8 \pm 0.4$ & $90 \pm 0.4$ & $130 \pm 6$ & $0.12-17.0$ & 0.9993 & 0.004 & 0.011 \\
\hline 12 & Sinapic acid & nd & nd & $54 \pm 2$ & $0.12-17.0$ & 0.9993 & 0.017 & 0.053 \\
\hline 13 & Benzoic acid & $50 \pm 0.6$ & $50 \pm 0.6$ & $1386 \pm 26$ & $0.85-55.0$ & 0.9998 & 0.111 & 0.335 \\
\hline 14 & o-Coumaric acid & $82 \pm 2$ & $82 \pm 2$ & nd & $0.24-32.0$ & 0.9988 & 0.023 & 0.069 \\
\hline 15 & Rutin & nd & nd & nd & $0.40-56.0$ & 0.9989 & 1.113 & 3.373 \\
\hline 16 & Hesperidin & nd & nd & nd & $0.43-55.0$ & 0.9992 & 1.080 & 3.280 \\
\hline 17 & Rosmarinic acid & $76 \pm 2$ & $1960 \pm 22$ & nd & $0.02-7.0$ & 0.9998 & 0.148 & 0.447 \\
\hline 18 & Eriodictyol & nd & nd & $116 \pm 4$ & $0.33-21.0$ & 0.9998 & 0.140 & 0.410 \\
\hline 19 & trans-Cinnamic acid & $18 \pm 1$ & $66 \pm 1.2$ & $10 \pm 1$ & $0.02-7.0$ & 0.9998 & 0.148 & 0.447 \\
\hline 20 & Quercetin & nd & nd & $1356 \pm 42$ & $0.40-55.0$ & 0.9999 & 0.013 & 0.040 \\
\hline 21 & Luteolin & $756 \pm 56$ & $908 \pm 56$ & $1006 \pm 56$ & $0.13-17.0$ & 0.9999 & 0.020 & 0.060 \\
\hline 22 & Kaempferol & nd & $288 \pm 6$ & $222 \pm 4$ & $0.05-15.0$ & 0.9996 & 0.021 & 0.062 \\
\hline 23 & Apigenin & $4136 \pm 94$ & $3314 \pm 86$ & $850 \pm 24$ & $0.17-11.0$ & 0.9997 & 0.034 & 0.104 \\
\hline
\end{tabular}

nd, not detected.

quantified as the dominant phenolic in the ethyl acetate and methanol extracts. Other dominant phenolics were luteolin, epicatechin, and rosmarinic acid in these extracts. However, the most abundant phenolics in the water extract were benzoic acid and quercetin. In recent studies, the detected phenolics in $O$. natrix extracts possess a broad range of biological activities including antioxidant, anticancer, antimicrobial and enzyme inhibitory (López-Lázaro, 2009; Amoah et al., 2016; David et al., 2016). In this framework, the observed biological activities for $O$. natrix extracts might be explained with the presence of these phenolic components. To the best of our knowledge, this study is the first report which indicates comprehensive analysis of phenolic constituents of $O$. natrix. In this sense, the present findings could be opened new horizons for the genus Ononis and it' usages.

\section{Antioxidant Capacity}

In order to evaluate antioxidant ability of $O$. natrix extracts, several methods were performed: free radical scavenging (DPPH and ABTS), reducing power (CUPRAC and FRAP), phosphomolybdenum and metal chelating assays. DPPH and ABTS assays are widely utilized to examine radical scavenging activities of plant extracts or synthetics. These assays are based on the reduction of $\mathrm{ABTS}^{+}$and DPPH in the presence of antioxidants and the changes (from blue to white in ABTS; from purple to yellow in DPPH) can spectrophotometrically be recorded. In addition, the assays reflect to hydrogen donating abilities of antioxidants. As shown in Table 3, the methanol and water extracts had similar DPPH scavenging abilities whereas the lowest ability was observed in the ethyl acetate extract. However, ABTS radical scavenging abilities can be ranked as ethyl acetate> 
methanol>water. The apparent differences can be attributed to nature of these radicals (ABTS assay is considered as both hydrophilic and lipophilic antioxidant systems, while DPPH is only hydrophobic systems). Our findings are consistent with previous results, which were reported different results for DPPH and ABTS (Kim et al., 2002; Zengin et al., 2015, 2017; Bouhlali et al., 2017).

Reducing power is an important way in the antioxidant mechanisms and it reflects electron-donating abilities of antioxidants. From this point, CUPRAC and FRAP assays were performed to detect reducing abilities of $O$. natrix extracts (Table 5). By using CUPRAC assay (from $\mathrm{Cu}^{2+}$ to $\mathrm{Cu}$ ), the ethyl acetate extract showed the strongest reducing ability, followed by methanol and water extracts. These results are in line with the total phenolic and flavonoid contents. Nevertheless, the FRAP (from $\mathrm{Fe}^{3+}$ to $\mathrm{Fe}^{2+}$ ) abilities decreased in that order water (106.12 mgTE/g extract) > ethyl acetate $(90.71 \mathrm{mgTE} / \mathrm{g}$ extract) $>$ methanol (79.73 $\mathrm{mgTE} / \mathrm{g}$ extract). This finding for water extract in FRAP assay might be related to complex interactions of phytochemical (antagonistic etc.) described as Peña-Cerda et al. (2017) and (Hmid et al., 2017).

Phosphomolybdenum assays is proposed by Prieto et al. (1999), which is based on the reduction of Mo (VI) to Mo (V) by the antioxidants and then a green phosphate/Mo (V) complex occurs at the acidic $\mathrm{pH}$. The assay is also considered as one of total antioxidant capacity assays. Within $O$. natrix extracts, the methanol extract ( $1.53 \mathrm{mmolTE} / \mathrm{g}$ extract) exerted the strongest ability in phosphomolybdenum assay, followed by ethyl acetate (1.27 mmolTE/g extract) and water (1.13 mmolTE/g extract) extracts (Table 4). In the literature, several researchers reported different approaches for a correlation between total phenolic and the reduction of Mo (VI) to Mo (V) (Albayrak et al., 2010; Kocak et al., 2016; Amessis-Ouchemoukh et al., 2017). At this point, this activity for the methanol extract may be related to the presence of other antioxidants as well as phenolics.

Transition metal ions, such as iron and copper are involved in the production of hydroxyl radical via Fenton and Haber-Weiss reactions. In this sense, the metal chelating ability is considered as an important way in the antioxidant mechanisms. Contrary to expectations, the metal chelating ability significantly differs from other antioxidant assays and the strongest activity was observed in water extract with $14.49 \mathrm{mgEDTAE} / \mathrm{g}$, while the ethyl acetate extract had the lowest ability (Table 5). These findings are consistent with previous studies, which reported no correlation between total phenolic and metal chelating ability (Silva et al., 2011; Hatami et al., 2014; Khorasani Esmaeili et al., 2015). In fact, the metal chelating abilities of phenolics were described as a minor way in theirs antioxidant properties by Rice-Evans et al. (1996).

\section{Enzyme Inhibitory Effect}

Alzheimer's diseases (AD) and diabetes mellitus (DM) are considered as major public health problems and their incidence tends to increase at an alarming rate (more than 35.6 million $\mathrm{AD}$ patients in worldwide and is expected to be more than 100 million $\mathrm{AD}$ patients by 2050). The development of new therapeutic approaches (also in terms of non-pharmacological therapy supplement) for these diseases has become a pressing issue. Among the therapeutic approaches, the inhibition of key enzymes is considered as one of most effective strategy (Wimo and Prince, 2010). Cholinesterase inhibitors are currently used as a drug for the treatment of $\mathrm{AD}$. The inhibitors increase brain acetylcholine (ACh) levels by preventing the breakdown of $\mathrm{ACh}$ and this case is very important to cognitive function (Menichini et al., 2014). Again, $\alpha$-amylase and $\alpha$-glucosidase release glucose from larger carbohydrates (especially starch) and are key enzymes in DM glucose level control (Kubinova et al., 2014). In this direction, both $\alpha$ amylase and $\alpha$-glucosidase inhibitors are promising drugs in the treatment of DM. In addition, tyrosinase is a main enzyme in the synthesis of melanin and thus tyrosinase inhibitors are useful for controlling hyperpigmentation problems. Within the framework of these information's, many enzyme inhibitors are synthetically produced. However, most of them show limited effectiveness especially related to side effects, such as gastrointestinal disturbances, and toxic properties (Kumar et al., 2011). Therefore, many scientists have focused on naturally occurring compounds from plants as potential sources of either new or safe effective inhibitors.

Thus, we tested enzyme inhibitory effects of Ononis extracts against to cholinesterases, tyrosinase, amylase and glucosidase. The results are represented in Table 6. The ethyl acetate extract exhibited the strongest cholinesterase inhibitory effect on both AChE (1.46 mgGALAE/g extract) and BChE (0.93 mgGALAE/g extract). However, the water extract was not active on BChE. The observed activity for ethyl acetate extract may be linked to higher level of phenolics in the extracts. Our findings were confirmed by several researchers (Kennedy and Wightman, 2011; Roseiro et al., 2012; Mazlan et al., 2013; Hlila et al., 2015), who reported a linear correlation between phenolic content and anti-cholinesterase abilities. Interestingly, the ethyl acetate extract did not have any inhibitory effect on tyrosinase and the

TABLE 5 | Total antioxidant capacity (phosphomolybdenum assay), reducing power (CUPRAC and FRAP assays) and metal chelating activities of the extracts.

\begin{tabular}{|c|c|c|c|c|}
\hline Extracts & Phosphomolybdenum (mmolTE/g extract) & CUPRAC (mgTE/g extract) & FRAP (mgTE/g extract) & Metal chelating (mgEDTAE/g extract) \\
\hline Ethyl acetate & $1.27 \pm 0.07^{\star}$ & $183.37 \pm 0.02$ & $90.71 \pm 1.79$ & $9.16 \pm 0.17$ \\
\hline Methanol & $1.53 \pm 0.08$ & $170.51 \pm 0.57$ & $79.73 \pm 1.17$ & $12.02 \pm 1.40$ \\
\hline Water & $1.13 \pm 0.03$ & $94.16 \pm 0.99$ & $106.12 \pm 0.44$ & $14.49 \pm 0.64$ \\
\hline
\end{tabular}

TE, trolox equivalents; EDTAE, EDTA equivalents.

*Values expressed are means \pm S.D. of three parallel measurements. 
water extract had remarkable anti-tyrosinase effect with 52.81 mgKAE/g extract. As for amylase and glucosidase inhibition, the ethyl acetate $(0.74 \mathrm{mmolACAE} / \mathrm{g}$ and $17.52 \mathrm{mmolACAE} / \mathrm{g})$ and methanol extracts ( $0.59 \mathrm{mmolACAE} / \mathrm{g}$ and $19.94 \mathrm{mmolACAE} / \mathrm{g})$ had the greatest abilities compared to water extract. The higher concentrations of phenolics in these extracts may be responsible for their anti-diabetic effects. In accordance with our findings, some phenolic components were reported as anti-diabetic agents (Tundis et al., 2010; Etxeberria et al., 2012; Ríos et al., 2015). From this point, molecular approaches could be valuable to understand interactions of enzymes and phenolics. To the best of our knowledge, this study is the first report on Ononis natrix

TABLE 6 | Enzyme inhibitory effects of the extracts.

\begin{tabular}{|c|c|c|c|c|c|}
\hline Extracts & $\begin{array}{l}\text { AChE inhibition } \\
\text { (mgGALAE/g } \\
\text { extract) }\end{array}$ & $\begin{array}{l}\text { BChE ınhibition } \\
\text { (mgGALAE/g } \\
\text { extract) }\end{array}$ & $\begin{array}{l}\text { Tyrosinase inhibition } \\
\text { (mgKAE/g extract) }\end{array}$ & $\begin{array}{c}\alpha \text {-amylase inhibition } \\
\text { (mmolACAE/g } \\
\text { extract) }\end{array}$ & $\begin{array}{c}\alpha \text {-glucosidase } \\
\text { Inhibition (mmolACAE/g } \\
\text { extract) }\end{array}$ \\
\hline Ethyl acetate & $1.46 \pm 0.07^{*}$ & $0.93 \pm 0.01$ & na & $0.74 \pm 0.02$ & $17.52 \pm 0.28$ \\
\hline Methanol & $1.29 \pm 0.05$ & $0.64 \pm 0.06$ & $11.20 \pm 2.30$ & $0.59 \pm 0.01$ & $19.94 \pm 0.11$ \\
\hline Water & $0.02 \pm 0.01$ & na & $52.81 \pm 5.15$ & $0.17 \pm 0.01$ & $3.69 \pm 0.17$ \\
\hline
\end{tabular}

GALAE, galanthamine equivalents; ACAE, acarbose equivalents; KAE, kojic acid equivalents; na, not active.

*Values expressed are means \pm S.D. of three parallel measurements.

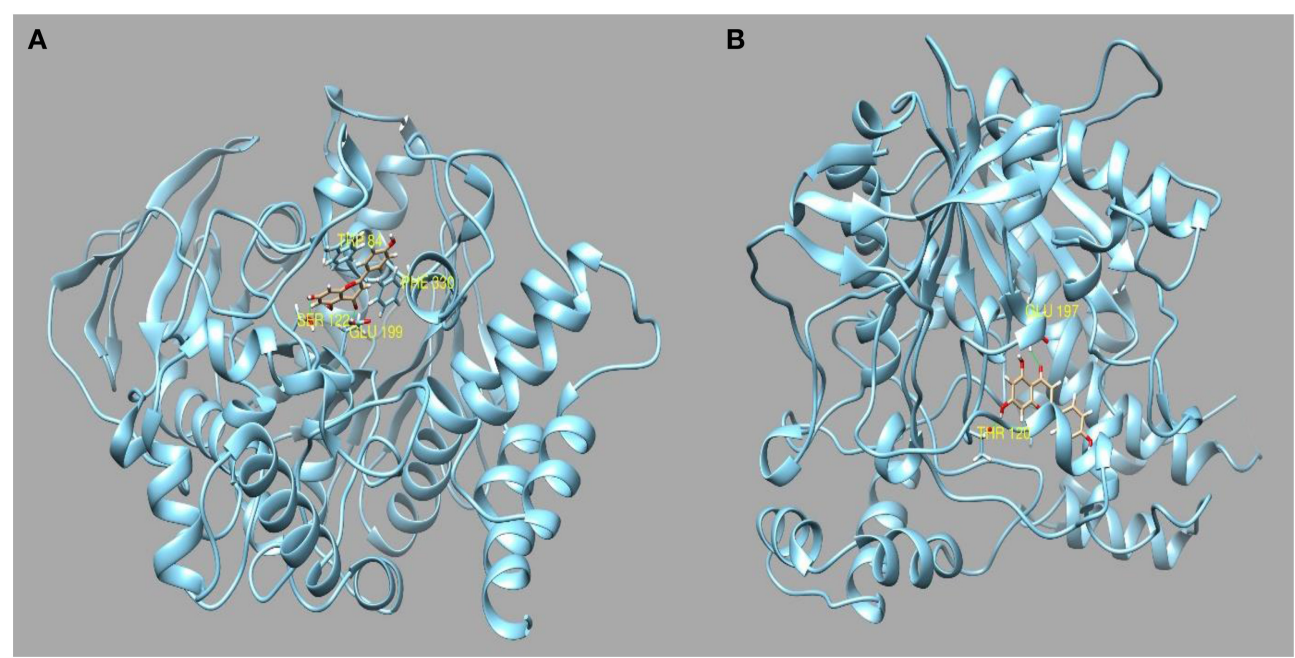

FIGURE 2 | (A) Best pose of apigenin docked to AChE and (B) to BChE.

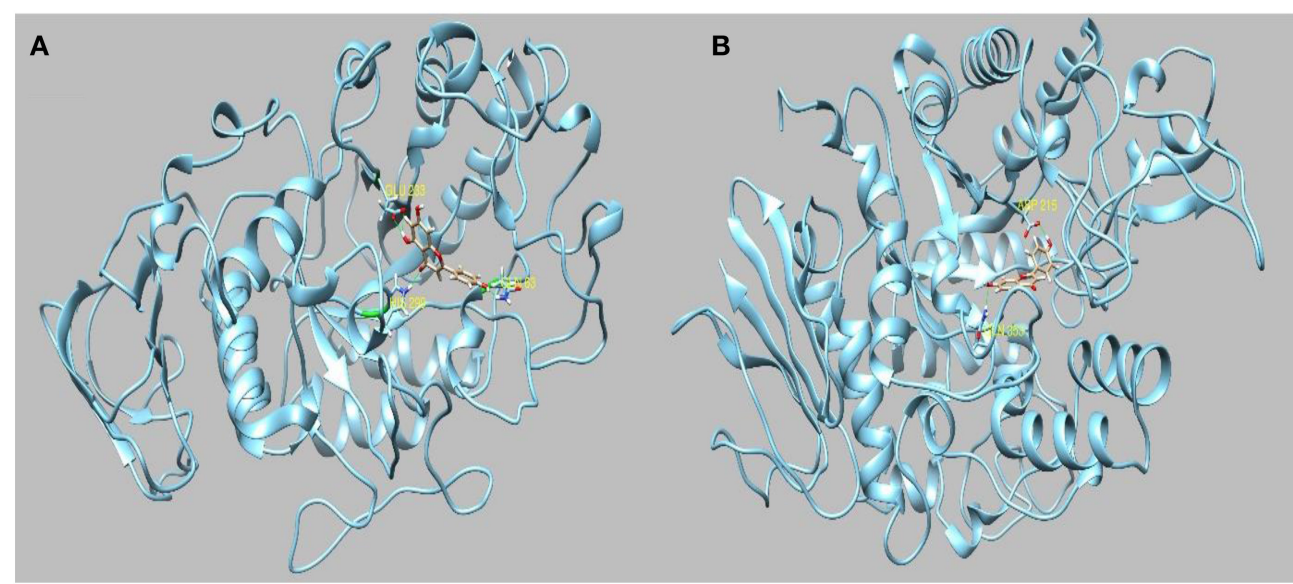

FIGURE 3 | (A) Best pose of apigenin docked to $\alpha$-amylase and (B) to $\alpha$-glucosidase. 
subsp. hispanica. Taken together, this study could provide a starting point on this species and could open new perspectives for designing novel functional products.

\section{Molecular Docking}

Evidence from the literature supports the inhibitory action of apigenin on AChE and BChE (Katalinić et al., 2010; Xie et al., 2014). Apigenin was also reported to induce moderate inhibitory effect on $\alpha$-amylase (Li et al., 2014; Wulan et al., 2014) and on $\alpha$-glucosidase. On the other hand, we have found that the water extract possesses good inhibition activity toward tyrosinase. This may be attributed to the presence of luteolin and quercetin. In light of the observed inhibitory activity, in silico molecular docking simulation was used to investigate the interactions between apigenin to AChE, BChE, amylase and glucosidase, whereas luteolin and quercetin have been selected as principal

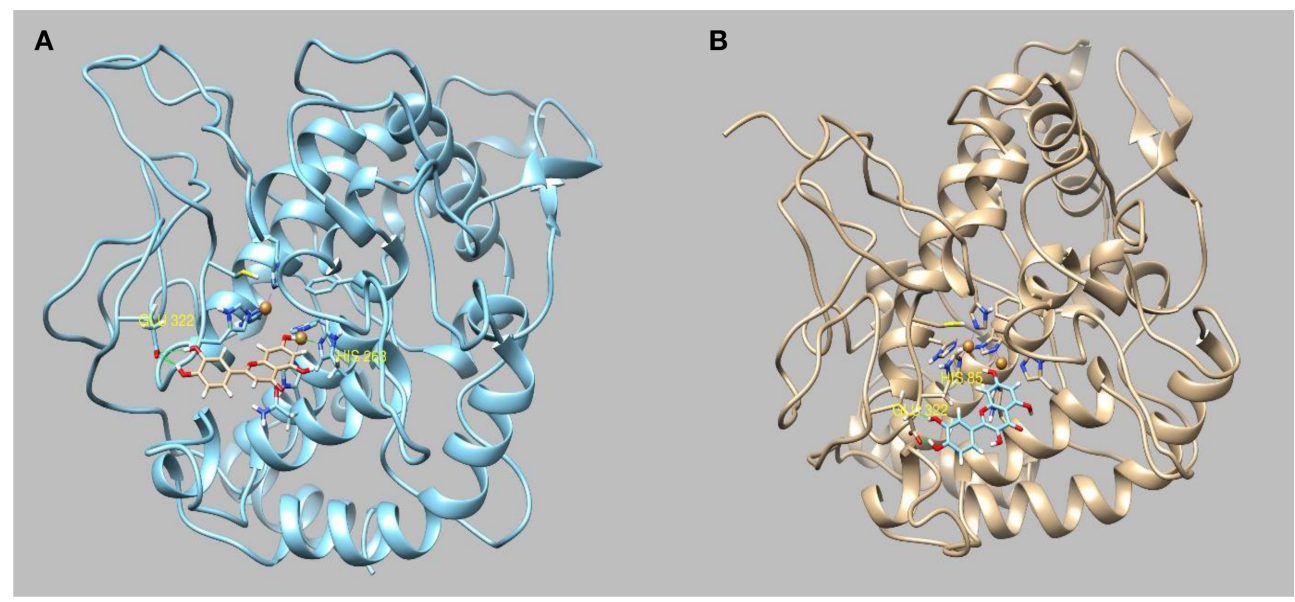

FIGURE 4 | Best pose of (A) luteolin and (B) quercetin docked to tyrosinase.
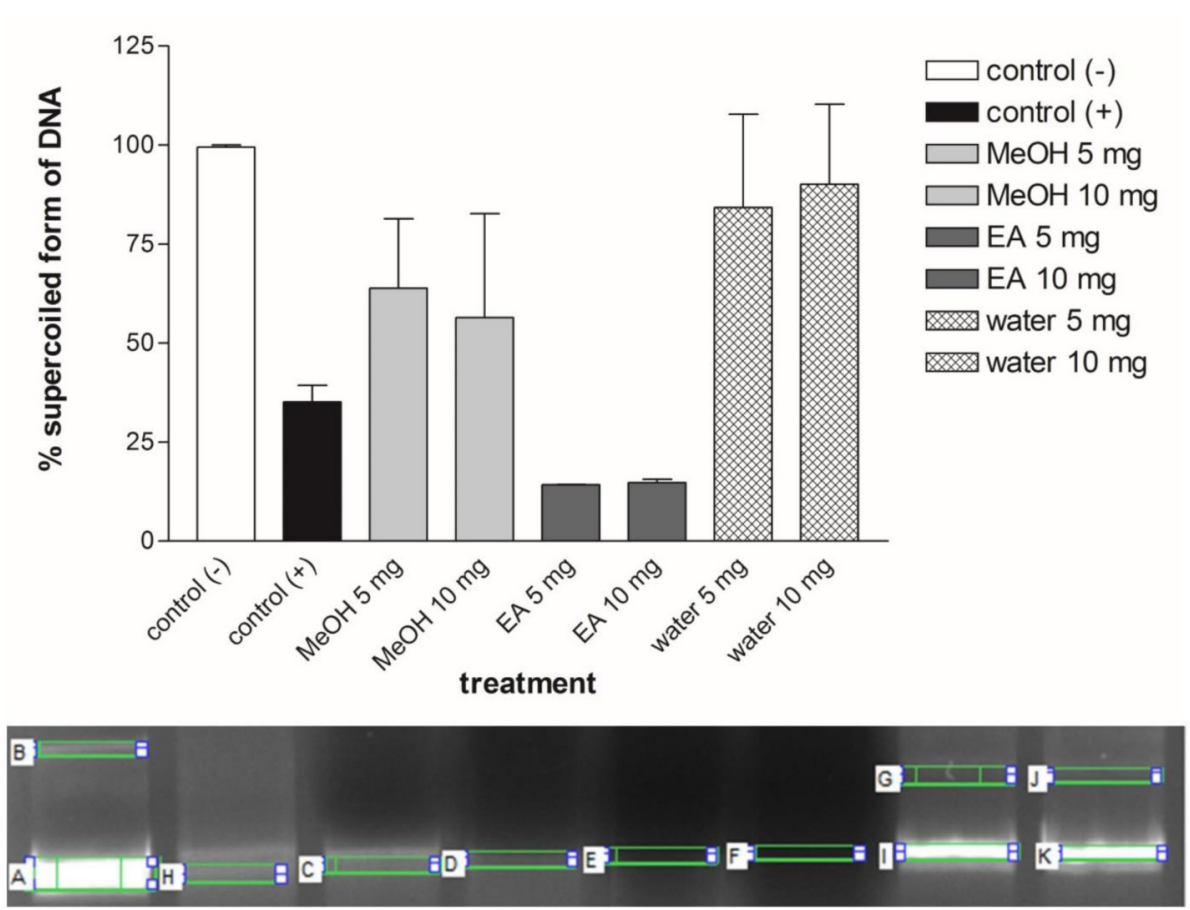

FIGURE 5 | percentage of DNA protection analysis and gel view of plasmid DNA protection test for each Ononis natrix extracts. A,B: (+) control, H: (-) control, C: $5 \mathrm{mg}$ methanol extract, D: $10 \mathrm{mg}$ methanol extract, E: $5 \mathrm{mg}$ ethyl acetate extract, F: $10 \mathrm{mg}$ ethyl acetate extract, I-G: 5 mg water extract, K-J: 10 mg water extract. Striped bars indicate significantly different applications. 
inhibitors of tyrosinase. The most representative enzyme-ligand complexes were reported in Figures 2-4.

Apigenin has been previously reported to inhibit both AChE and BChE by IC50 of $7.72 \mathrm{micro} / \mathrm{Mol}$ (Balkis et al., 2015) and 37.4 micro/Mol (Katalinić et al., 2010), respectively. The best docked pose interacts with AChE in the binding pocked by establishing two hydrogen bonds to Glu199 and Ser122 and two pi-pi stacks to Phe330 and Trp 84 with a docking score of -9.607 and a binding energy of $-60.64 \mathrm{Kcal} / \mathrm{Mol}$. Apigenin also interacts with several residues present in the binding pocket of BChE forming two hydrogen bonds to Thr120 and Glu197 with a docking score of -9.459 and a binding energy of -52.54 $\mathrm{kcal} / \mathrm{Mol}$. Also, considering the abundance in the ethyl acetate and methanol extracts, apigenin could be also responsible for the amylase and glucosidase inhibiting activity. Indeed, it has been previously reported that apigenin was an efficacious inhibitor of $\alpha$-glucosidase with a IC50 of and a moderate $\alpha$-amylase inhibitor with a IC50 of $10.5 \mu / \mathrm{Mol}$ (Zeng et al., 2016).

Apigenin interacts with $\alpha$-glucosidase by forming two hydrogen bonds to Asp215 and Gln353 and with the enzymatic cavity of $\alpha$-amylase by forming three hydrogen bonds to Gln63, His299, and Glu233. The aqueous extract has shown a strong activity toward tyrosinase. The most abundant substances present in the extracts are benzoic acid, luteolin and quercetin. All of these substances have been demonstrated to have an tyrosinase inhibitory activity in in vitro experiments (IC50 = quercetin 0.13 $\mathrm{mM}$ ) (Chen and Kubo, 2002). However, benzoic acid reported a scarce docking score $(-5.1)$ and a positive binding energy $(+41.7 \mathrm{Kcal} / \mathrm{Mol})$ which indicate none or very little affinity for the binding pocket of the enzyme, whereas the luteolin and quercetin have obtained the best binding energy. ( $-28 \mathrm{Kcal} / \mathrm{Mol}$ and $-29.31 \mathrm{Kcal} / \mathrm{Mol}$, respectively).

However, it is noteworthy to highlight that the plant extracts contain several phenolic compounds which in less extent are able to inhibit the tested enzymes all with non-competitive mechanism as demonstrated in our previous paper (Picot et al., 2017). Inhibitory action of the plant extracts on AChE, BChE, tyrosinase, $\alpha$-amylase, and $\alpha$-glucosidase might be due to the concerted action of several phenolic compounds rather than a single molecule.

\section{DNA Protective Effects}

Various stress factors, such as oxidative stress, acid, alkaline, UV, and heavy metals can damage DNA. ROS formed by hydroxyl radicals cause DNA strand breakage that is brought about carcinogenesis, mutagenesis and cytotoxicity (Golla and Bhimathati, 2014). Here, we targeted to measure the DNA damage by Fenton reaction-mediated oxidative stress. Fenton's reagent $\left(\mathrm{Fe}^{2+}+\mathrm{H}_{2} \mathrm{O}_{2} \rightarrow \mathrm{Fe}^{3+}+\mathrm{OH}^{-}+\cdot \mathrm{OH}\right)$ produces the highly deleterious hydroxyl radicals that damage the cellular components, such as DNA, lipid and proteins. The scavenging effect of extract was tested in plasmid nicking assay. Figure 5 illustrates the DNA protection activity of the Ononis extracts with two different concentrations ( 5 and $10 \mathrm{mg} / \mathrm{ml}$ ). Ononis extracted in water $(10 \mathrm{mg} / \mathrm{ml})$ had the most effective on protection of DNA with $78 \%$, followed by water $(5 \mathrm{mg} / \mathrm{ml})(70 \%)$ and methanol extract with $5 \mathrm{mg} / \mathrm{ml}$ (53\%). Except for the ethyl acetate extract $(5$ and $10 \mathrm{mg} / \mathrm{ml}$ ), water and methanol extracts protected supercoiled form of pDNA and indicated DNA protection activity.
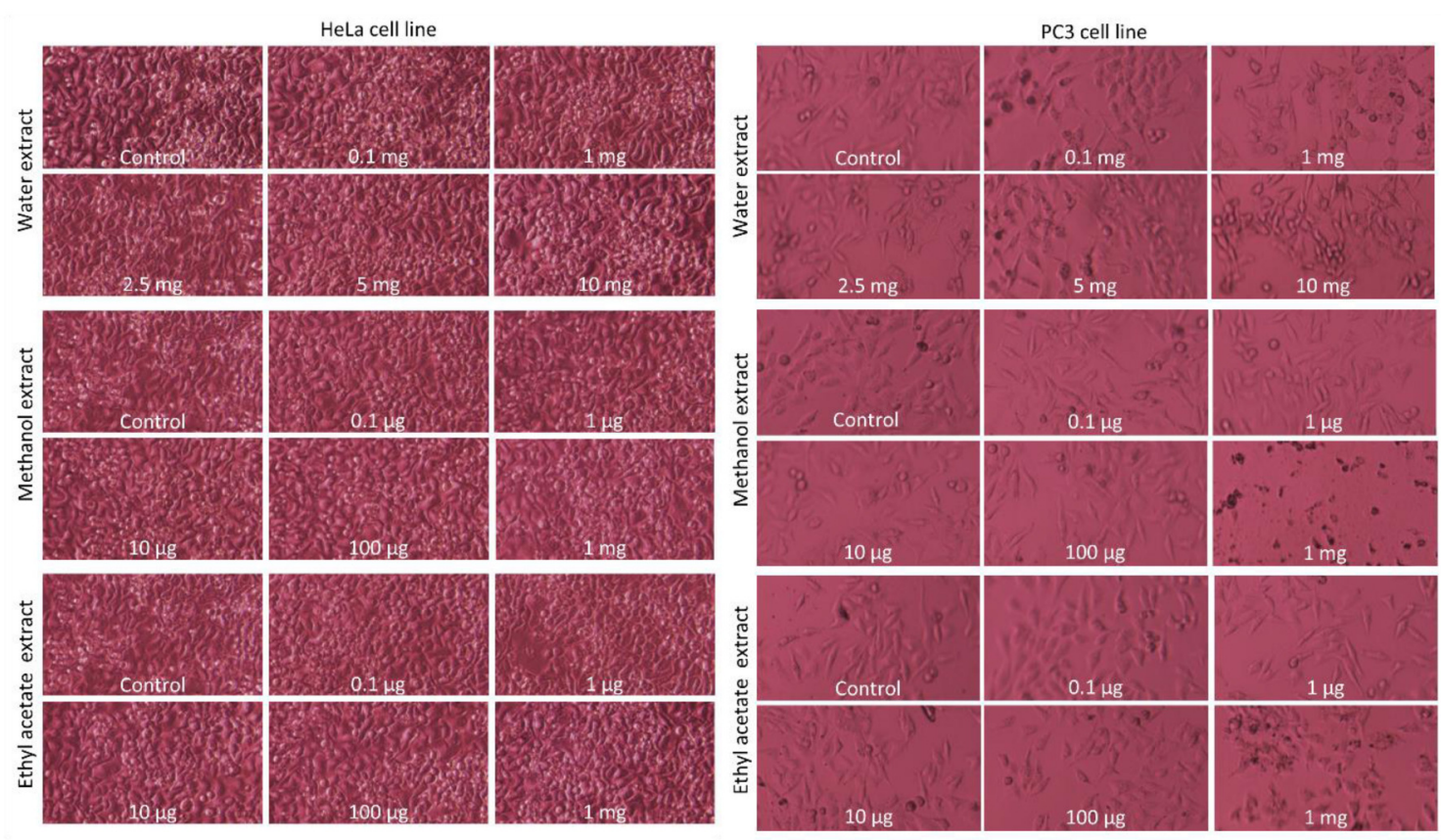

FIGURE 6 | Cells morphology of HeLA and PC3 cancer cell lines after application of different extracts of Ononis natrix. Control and different concentrations of extracts were tested in HeLA or PC3 cancer cell lines and indicated for each figures. 
In the present study, the water extract had the most protection activity on DNA. This can be arisen from availability of different metabolites in water extract. Quercetin and sinapic acid are only metabolites which found in this extract. So, it can be concluded that these chemicals may be responsible for protection of DNA from Fenton reagent. Like water extract, the methanol extract also contained specific metabolite, such as rosmarinic acid. In this sense, the observed DNA protection ability for the methanol extract can be arisen from presence of higher amount of rosmarinic acid. Therefore, it seems that different ingredients of the extracts may cause formation of DNA protection property for the tested extracts. According to DNA protection assay results, water extract of Ononis natrix showed the most protective activity for DNA. This result may be explained by determination of phenolic components in the extracts using HPLC analysis. As indicated in Table 4, rosmarinic acid and quercetin were the most dissolved components in methanol and water extracts of Ononis natrix, respectively. So, it can be concluded that rosmarinic acid and quercetin can be considered as potential chemicals for protection of DNA from free radicals, hydroxyl radicals and mutagens. Quercetin is a well-investigated antioxidant known as promising molecule for pharmacological studies. In a comprehensive research for DNA protection ability of quercetin, its supplementation indicated protection of nuclear DNA from oxidative damage and significant genoprotective activity on mitochondrial DNA (Potenza et al., 2008). In a different study, three polyphenolic compounds including luteolin, quercetin and rosmarinic acid, were investigated for their protective effects against oxidative DNA damage (Silva et al., 2008). They found that all of these phenolics were protection agents against oxidative stress-induced DNA damage. In another search, protective activity of pure rosmarinic acid and elagic acid were evaluated. It has been found that they have equal effect on declining AAPH-induced oxidative DNA damage (Vattem et al., 2006). These results are in accord with our study indicating that methanol and water extracts of Ononis natrix can be considered
HeLa cell line
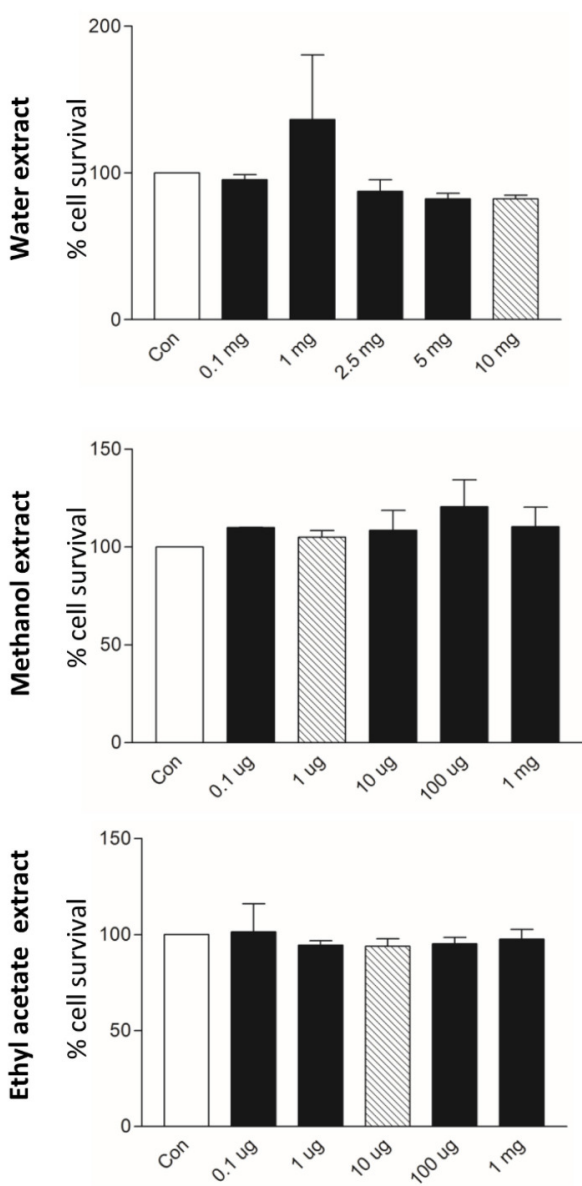

PC3 cell line
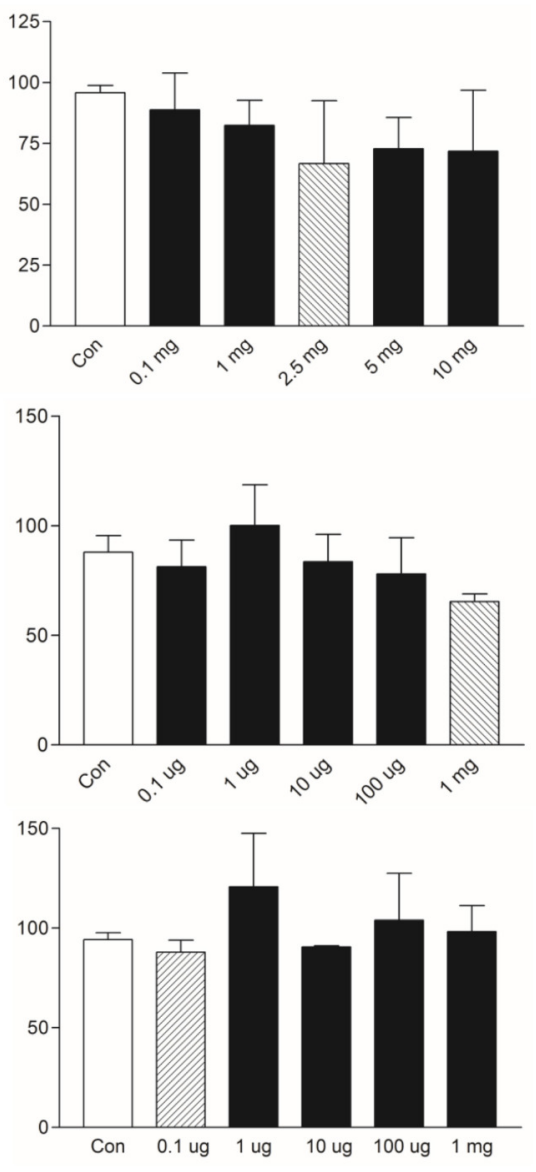

FIGURE 7 | Cell viability assay (MTT) analysis of HeLA and PC3 cancer cell lines after application of different extracts of Ononis natrix. White bars and striped bars indicate controls and significantly different applications, respectively. 
as valuable DNA protectors because of presence of rosmarinic acid and quercetin.

\section{Cytotoxic Effects}

The cytotoxic effects of Ononis natrix on the survival of HeLa and PC3 cells were determined by MTT cell viability assay. HeLa cervical cancer cell line and PC3 prostate cancer cell line were treated with these extracts with different concentrations for $24 \mathrm{~h}$. Cells morphology was observed under inverted microscope and illustrated in Figure 6. According to morphological appearance, there was no significant apoptotic effect on Ononis natrix extracts for HeLa cell line. However, the water and methanol extracts caused initiation of apoptosis for PC3 cell line. To indicate effect of three extracts on cancer cell lines, cell viability assay (MTT) was also conducted. Although there was a cytotoxic activity for HeLa cells after application of the water extract, no significant decline was observed in cancer cell numbers compared to control (Figure 7). On the other hand, $2.5 \mathrm{mg}$ water extract, $1 \mathrm{mg}$ methanol extract and $0.1 \mu \mathrm{g}$ ethyl acetate extract caused a significant cell number reduction on PC3 cancer line (Figure 7). Ethyl acetate extract indicated cytotoxic activity with the smallest concertation $(0.1 \mu \mathrm{g})$ among all extracts. $2.5 \mathrm{mg}$ of the water extract showed dose-independent cytotoxic effect on PC3 cell line since there was no effect for $5 \mathrm{mg}$ and $10 \mathrm{mg}$ water extracts. It has been considered that concentration of water extract more than $2.5 \mathrm{mg}$ may be toxic against healthy or normal viable cells. Thus, it can be concluded that $2.5 \mathrm{mg}$ is a moderate concentration for cytotoxicity on PC3 cancer cell line. It was also monitored that other treatments had cytotoxic effect whereas, they were not significantly different from control sample anymore.

According to reports, about $60 \%$ of anticancer drugs are isolated from plant-derived natural compounds. These medicinal plants highly contain polyphenolic compounds which are actually inhibitors for cancer development (Sukumaran et al., 2016). Cytotoxic and apoptotic effects of the studied extracts on HeLa and PC3 cell lines were investigated. Although there was no significant variation on HeLa cells, $2.5 \mathrm{mg}$ of water and $1 \mathrm{mg}$ methanol extracts leaded to cytotoxic activity compared to control in PC3. Some of phenolic compounds show antiproliferative effect which depends on polarity of compounds. Cytotoxic effect of methanol extract can be explained with the presence of rosmarinic acid, apigenin, and epicatechin. Effect of anti-carcinogenic and scavenging of reactive oxygen radicals of rosmaniric acid were particularly searched in Perilla frutescens (Osakabe et al., 2004). The body's response to cancer showed parallel effects with the inflammatory response. Since, inflammatory cytokine networks may affect survival, growth, mutation, proliferation, differentiation and relocation of tumor and stromal cells (David, 1988; Balkwill and Mantovani, 2001; Osakabe et al., 2004). Rosmaniric acid is a water-soluble polyphenolic compound and has function on inhibition of angiogenesis (Huang and Zheng, 2006). There was a potential evidence that ROS acts as initiating angiogenesis and onset of cancer mechanism. It was proved that hydrogen peroxide stimulated angiogenesis in vitro condition (Shono et al., 1996; Yasuda et al., 1999; Huang and Zheng, 2006). Rosmaniric acid reduced ROS expression, hydrogen peroxide level and VEGF
(Vascular Endothelial Growth Factor) level that are important on cancer development (Huang and Zheng, 2006). Furthermore, the previous report which indicated effect of methanolic extract of plant species on antioxidant activity and examination of level of rosmaniric acid (Tepe, 2008). In addition, in our previous study, three extracts (ethyl acetate, methanol and water) of two Potentilla species (Potentilla reptans and P. speciosa) showed cytotoxic activity against A549 andMCF-7 due to some phenolic compounds (Uysal et al., 2017). The findings of this analysis suggest that one or more than one phenolic compounds and their interaction may cause initiation of apoptosis in cancer cell lines. However, further investigation should be performed in in vivo test to arrive at a definite judgment for inhibition of cancer development.

\section{Antimicrobial Effects}

Antimicrobial activity of the extracts from O. natrix subsp. hispanica were searched against to 13 bacteria and 1 fungus by the disk diffusion method. The extracts were loaded the disks at the concentration of 10,50, and $100 \mathrm{mg}$. According to results, 50 and $100 \mathrm{mg}$ of methanol and ethyl acetate extracts showed the best antibacterial effect against to Staphylococcus aureus ATCC 25923 and Staphylococcus epidermidis strains (Figure 8). In addition, $100 \mathrm{mg}$ water extracts had a small effect on Salmonella kentucky. It was realized that extracts possessed more protective effect against to gram positive bacteria strains. In addition, concentration-dependent effect was also observed. For example, S. epidermis stain was more sensitive against to $100 \mathrm{mg}$ of methanol and ethyl acetate extracts than $50 \mathrm{mg}$ ones. Methanol and ethyl acetate extracts of $O$. natrix subsp. hispanica were more effective than water extract for antimicrobial analysis. The results of this analysis support the idea that because of higher total phenolic and flavonoid contents of methanol and ethyl acetate

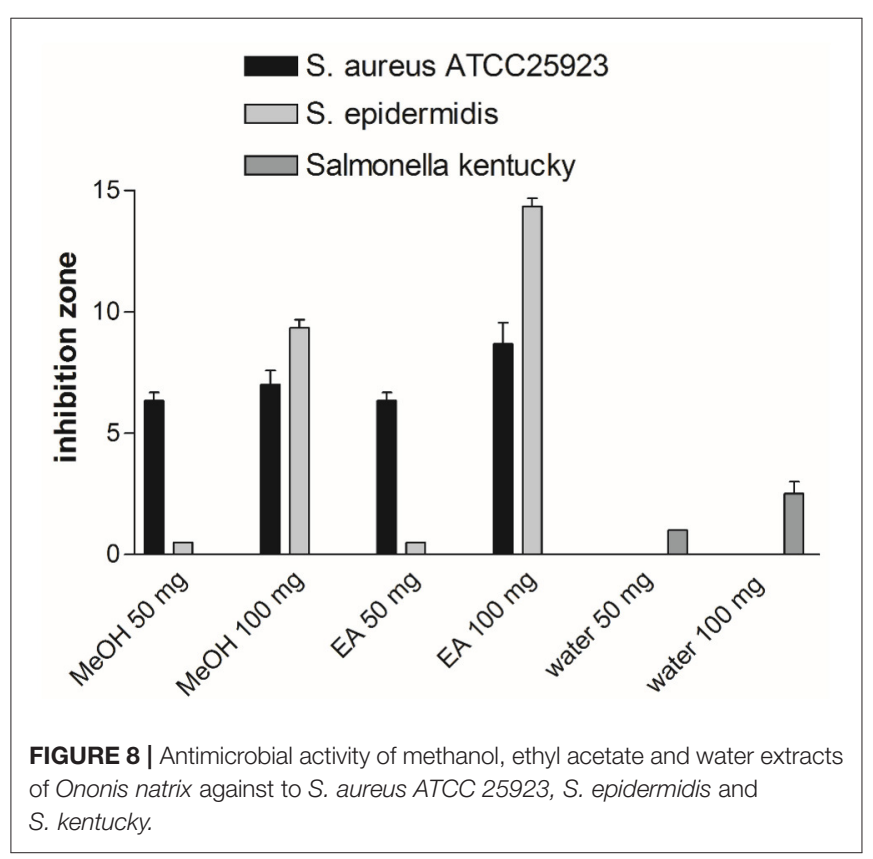


extracts, they indicated more antimicrobial activity than water one.

Staphylococcus aureus (ATCC 25923) is a gram positive bacterium and causes several human infections and leads to sanitary problems. S. aureus also shows resistance to some antibiotics and drugs particularly to methicillin (Hannan et al., 2008). Resistance problems induced to researchers to tend for seeking novel therapy. S. epidermidis together with $S$. aureus lead to severe infectious diseases (Otto, 2009). S. epidermidis is more being tend to cause infectious diseases due to developing persistent infection on human skin (Otto, 2009). Researchers are seeking the mechanisms by which $S$. epidermidis promotes diseases (Otto, 2009). In a study of Sayari et al. (2016) Ononis natrix leaves extracts were tested against to 9 bacterial strains (5 gram-negative and 4 gram-positive). Consistently with our study, $S$. aureus were the most susceptible against to Ononis natrix leaves extracts. In another study, $S$. aureus (ATCC 25923), and E. coli (ATCC 25922) were found to have more sensitivity against the Ononis natrix essential oils with inhibition zone as 27 and 25, respectively (Elamrani and Benaissa, 2010).

\section{REFERENCES}

Albayrak, S., Aksoy, A., Sagdic, O., and Hamzaoglu, E. (2010). Compositions, antioxidant and antimicrobial activities of Helichrysum (Asteraceae) species collected from Turkey. Food Chem. 119, 114-122. doi: 10.1016/j.foodchem.2009.06.003

Al-Rehaily, A. J., Shamim Ahmad, M., Yousaf, M., Iqrar Khan, S., Mustafa, J., Tekwani, B. L., et al. (2014). Bioactive chemical constituents of Ononis natrix. J. Chem. Soc. Pak. 36, 1114-1121.

Amessis-Ouchemoukh, N., Ouchemoukh, S., Meziant, N., Idiri, Y., Hernanz, D., Stinco, C. M., et al. (2017). Bioactive metabolites involved in the antioxidant, anticancer and anticalpain activities of Ficus carica L., Ceratonia siliqua L. and Quercus ilex L. extracts. Ind. Crops Prod. 95, 6-17. doi: 10.1016/j.indcrop.2016.10.007

Amoah, S. K., Sandjo, L. P., Kratz, J. M., and Biavatti, M. W. (2016). Rosmarinic acid-pharmaceutical and clinical aspects. Planta Med. 82, 388-406. doi: 10.1055/s-0035-1568274

Balkis, A., Tran, K., Lee, Y. Z., and Ng, K. (2015). Screening flavonoids for inhibition of acetylcholinesterase identified baicalein as the most potent inhibitor. J. Agric. Sci. 7, 26-35. doi: 10.5539/jas.v7n9p26

Balkwill, F., and Mantovani, A. (2001). Inflammation and cancer: back to Virchow? Lancet 357, 539-545. doi: 10.1016/S0140-6736(00)04046-0

Baytop, T. (1999). Therapy with Medicinal Plants in Turkey (Past and Present). Istanbul: Nobel Tip Basimevi.

Berman, H. M., Westbrook, J., Feng, Z., Gilliland, G., Bhat, T. N., Weissig, H., et al. (2000). The protein data bank. Nucleic Acids Res. 28, 235-242. doi: $10.1093 / \mathrm{nar} / 28.1 .235$

Bouhlali, E. D. T., Ramchoun, M., Alem, C., Ghafoor, K., Ennassir, J., and Zegzouti, Y. F. (2017). Functional composition and antioxidant activities of eight Moroccan date fruit varieties (Phoenix dactylifera L.). J. Saudi Soc. Agric. Sci. 16, 257-264. doi: 10.1016/j.jssas.2015.08.005

Casiglia, S., Bruno, M., and Senatore, F. (2017). Chemical composition of the essential oil from the aerial parts of Ononis reclinata L. (Fabaceae) grown wild in Sicily. Nat. Prod. Res. 31, 7-15. doi: 10.1080/14786419.2016.1205054

Chen, Q.-X., and Kubo, I. (2002). Kinetics of mushroom tyrosinase inhibition by quercetin. J. Agric. Food Chem. 50, 4108-4112. doi: 10.1021/jf011378z

Daruházi, Á. E., Szarka, S., Héthelyi, É., Simándi, B., Gyurján, I., László, M., et al. (2008). GC-MS identification and GC-FID quantitation of terpenoids in Ononidis spinosae radix. Chromatographia 68, 71-76. doi: 10.1365/s10337-008-0679-2

\section{CONCLUSION}

In recent years, pharmaceuticals and functional ingredients from plant sources have been of paramount interest. In this sense, chemical profile and biological abilities of $O$. natrix subsp. hispanica were investigated in the current work. As far as we aware, this work is the first report on this species. The tested extracts, especially ethyl acetate and methanol, exhibited notable biological effects correlated with higher levels of bioactive compounds. The results obtained from the present work provide a new framework for utilization of the genus Ononis and as a result, $O$. natrix subp. hispanica could be suggested as a natural source of bioactive agents, such as antioxidant, antimicrobial and anticancer. We hope that our research will serve a base for future studies for in vivo and bioavailability studies on $O$. natrix subsp. hispanica.

\section{AUTHOR CONTRIBUTIONS}

SY, GZ, MB, and YC set up and carried out experiments. AM and AA executed data analysis.

David, A. V. A., Arulmoli, R., and Parasuraman, S. (2016). Overviews of biological importance of quercetin: a bioactive flavonoid. Pharmacogn. Rev. 10, 84-89. doi: 10.4103/0973-7847.194044

David, H. (1988). Rudolf Virchow and modern aspects of tumor pathology. Pathol. Res. Pract. 183, 356-364. doi: 10.1016/S0344-0338(88)80138-9

DeLano, W. L. (2002). The PyMOL Molecular Graphics System. Palo Alto, CA.

Do, Q. D., Angkawijaya, A. E., Tran-Nguyen, P. L., Huynh, L. H., Soetaredjo, F. E., Ismadji, S., et al. (2014). Effect of extraction solvent on total phenol content, total flavonoid content, and antioxidant activity of Limnophila aromatica. J. Food Drug Anal. 22, 296-302. doi: 10.1016/j.jfda.2013.11.001

Elamrani, A., and Benaissa, M. (2010). Chemical composition and antibacterial activity of the essential oil of Ononis natrix from morocco. J. Essent. Oil Bear. Plants 13, 477-488. doi: 10.1080/0972060X.2010.10643852

Erdemgil, F., Kurkcuoglu, M., and Baser, K. (2002). Composition of the essential oil of Ononis viscosa subsp. breviflora. Chem. Nat. Comp. 38, 565-567. doi: 10.1023/A:1022686721070

Etxeberria, U., De La Garza, A. L., Campión, J., Martinez, J. A., and Milagro, F. I. (2012). Antidiabetic effects of natural plant extracts via inhibition of carbohydrate hydrolysis enzymes with emphasis on pancreatic alpha amylase. Expert Opin. Ther. Targets 16, 269-297. doi: 10.1517/14728222.2012.664134

Fernandes, L., Casal, S., Pereira, J. A., Saraiva, J. A., and Ramalhosa, E. (2017). Edible flowers: a review of the nutritional, antioxidant, antimicrobial properties and effects on human health. J. Food Composit. Anal. 60, 38-50. doi: 10.1016/j.jfca.2017.03.017

Gampe, N., Darcsi, A., Lohner, S., Béni, S., and Kursinszki, L. (2016). Characterization and identification of isoflavonoid glycosides in the root of Spiny restharrow (Ononis spinosa L.) by HPLC-QTOF-MS, HPLC-MS/MS and NMR. J. Pharm. Biomed. Anal. 123, 74-81. doi: 10.1016/j.jpba.2016. 01.058

Ghribi, L., Nejma, A. B., Besbes, M., Harzalla-Skhiri, F., Flamini, G., and Jannet, H. B. (2016). Chemical composition, cytotoxic and antibacterial activities of the essential oil from the Tunisian Ononis angustissima L. (Fabaceae). J. Oleo Sci. 65, 339-345. doi: 10.5650/jos.ess 15242

Ghribi, L., Waffo-Téguo, P., Cluzet, S., Marchal, A., Marques, J., Mérillon, J.-M., et al. (2015). Isolation and structure elucidation of bioactive compounds from the roots of the Tunisian Ononis angustissima L. Bioorg. Med. Chem. Lett. 25, 3825-3830. doi: 10.1016/j.bmcl.2015.07.076

Golla, U., and Bhimathati, S. S. (2014). Evaluation of antioxidant and DNA damage protection activity of the hydroalcoholic extract of Desmostachya bipinnata L. Stapf. Sci. World J. 2014:215084. doi: 10.1155/2014/215084 
Hannan, A., Saleem, S., Chaudhary, S., Barkaat, M., and Arshad, M. U. (2008). Anti bacterial activity of Nigella sativa against clinical isolates of methicillin resistant Staphylococcus aureus. J. Ayub Med. Coll. Abbottabad 20, 72-74.

Hatami, T., Emami, S. A., Miraghaee, S. S., and Mojarrab, M. (2014). Total phenolic contents and antioxidant activities of different extracts and fractions from the aerial parts of Artemisia biennis Willd. Iran. J. Pharm. Res. 13:551.

Hlila, M. B., Mosbah, H., Mssada, K., Jannet, H. B., Aouni, M., and Selmi, B. (2015). Acetylcholinesterase inhibitory and antioxidant properties of roots extracts from the Tunisian Scabiosa arenaria Forssk. Ind. Crops Prod. 67, 62-69. doi: 10.1016/j.indcrop.2015.01.009

Hmid, I., Elothmani, D., Hanine, H., Oukabli, A., and Mehinagic, E. (2017). Comparative study of phenolic compounds and their antioxidant attributes of eighteen pomegranate (Punica granatum L.) cultivars grown in Morocco. Arab. J. Chem. 10, 2675-2684. doi: 10.1016/j.arabjc.2013.10.011

Huang, S. S., and Zheng, R. L. (2006). Rosmarinic acid inhibits angiogenesis and its mechanism of action in vitro. Cancer Lett 239, 271-280. doi: 10.1016/j.canlet.2005.08.025

Irwin, J. J., Sterling, T., Mysinger, M. M., Bolstad, E. S., and Coleman, R. G. (2012). ZINC: a free tool to discover chemistry for biology. J. Chem. Inf. Model. 52, 1757-1768. doi: 10.1021/ci3001277

Ismaya, W. T., Rozeboom, H. J., Weijn, A., Mes, J. J., Fusetti, F., Wichers, H. J., et al. (2011). Crystal structure of Agaricus bisporus mushroom tyrosinase: identity of the tetramer subunits and interaction with tropolone. Biochemistry 50, 5477-5486. doi: 10.1021/bi200395t

Jones, G., Willett, P., Glen, R. C., Leach, A. R., and Taylor, R. (1997). Development and validation of a genetic algorithm for flexible docking. J. Mol. Biol. 267, 727-748. doi: 10.1006/jmbi.1996.0897

Karakurt, S., and Adali, O. (2016). Tannic acid inhibits proliferation, migration, invasion of prostate cancer and modulates drug metabolizing and antioxidant enzymes. Anticancer. Agents Med. Chem. 16, 781-789. doi: 10.2174/1871520616666151111115809

Katalinić, M., Rusak, G., Barović, J. D., Šinko, G., Jelić, D., Antolović, R., and Kovarik, Z. (2010). Structural aspects of flavonoids as inhibitors of human butyrylcholinesterase. Eur. J. Med. Chem. 45, 186-192. doi: 10.1016/j.ejmech.2009.09.041

Kennedy, D. O., and Wightman, E. L. (2011). Herbal extracts and phytochemicals: plant secondary metabolites and the enhancement of human brain function. Adv. Nutr. 2, 32-50. doi: 10.3945/an.110.000117

Khorasani Esmaeili, A., Mat Taha, R., Mohajer, S., and Banisalam, B. (2015). Antioxidant activity and total phenolic and flavonoid content of various solvent extracts from in vivo and in vitro grown Trifolium pratense L. (red clover). Biomed Res. Int. 2015:643285. doi: 10.1155/2015/643285

Kim, D.-O., Lee, K. W., Lee, H. J., and Lee, C. Y. (2002). Vitamin C equivalent antioxidant capacity (VCEAC) of phenolic phytochemicals. J. Agric. Food Chem. 50, 3713-3717. doi: 10.1021/jf020071c

Kocak, M. S., Sarikurkcu, C., Cengiz, M., Kocak, S., Uren, M. C., and Tepe, B. (2016). Salvia cadmica: phenolic composition and biological activity. Ind. Crops Prod. 85, 204-212. doi: 10.1016/j.indcrop.2016.03.015

Kubinova, R., Porizkova, R., Navratilova, A., Farsa, O., Hanakova, Z., Bacinska, A., et al. (2014). Antimicrobial and enzyme inhibitory activities of the constituents of Plectranthus madagascariensis (Pers.) Benth. J. Enzym. Inhib. Med. Chem. 29, 749-752. doi: 10.3109/14756366.2013.848204

Kuete, V., Wiench, B., Alsaid, M. S., Alyahya, M. A., Fankam, A. G., Shahat, A. A., et al. (2013). Cytotoxicity, mode of action and antibacterial activities of selected Saudi Arabian medicinal plants. BMC Complement. Altern. Med. 13:354. doi: 10.1186/1472-6882-13-354

Kumar, S., Narwal, S., Kumar, V., and Prakash, O. (2011). $\alpha$-glucosidase inhibitors from plants: a natural approach to treat diabetes. Pharmacogn. Rev. 5, 19-29. doi: 10.4103/0973-7847.79096

Li, H.-R., Habasi, M., Xie, L.-Z., and Aisa, H. A. (2014). Effect of chlorogenic acid on melanogenesis of B16 melanoma cells. Molecules 19, 12940-12948. doi: 10.3390/molecules190912940

Liebezeit, G. (2008). Ethnobotany and phytochemistry of plants dominant in salt marshes of the Lower Saxonian Wadden Sea, southern North Sea. Mar. Biodiversity 38, 1-30. doi: 10.1007/BF03043865

López-Lázaro, M. (2009). Distribution and biological activities of the flavonoid luteolin. Mini Rev. Med. Chem. 9, 31-59. doi: 10.2174/138955709787001712

Losada-Barreiro, S., and Bravo-Díaz, C. (2017). Free radicals and polyphenols: the redox chemistry of neurodegenerative diseases. Eur. J. Med. Chem. 133, 379-402. doi: 10.1016/j.ejmech.2017.03.061
Maestro, S. (2015). Version 9.2. LLC. New York, NY.

Mazlan, N. A., Mediani, A., Abas, F., Ahmad, S., Shaari, K., Khamis, S., et al. (2013). Antioxidant, antityrosinase, anticholinesterase, and nitric oxide inhibition activities of three Malaysian Macaranga species. Sci. World J. 2013:312741. doi: 10.1155/2013/312741

Meeran, M. F. N., Javed, H., Al Taee, H., Sheikh, A., and Ojha, S. K. (2017). Pharmacological properties and molecular mechanisms of thymol: prospects for its therapeutic potential and pharmaceutical development. Front. Pharmacol. 8:380. doi: 10.3389/fphar.2017.00380

Menichini, F., Losi, L., Bonesi, M., Pugliese, A., Loizzo, M. R., and Tundis, R. (2014). Chemical profiling and in vitro biological effects of Cardiospermum halicacabum L. (Sapindaceae) aerial parts and seeds for applications in neurodegenerative disorders. J. Enzym. Inhib. Med. Chem. 29, 677-685. doi: 10.3109/14756366.2013.840614

Mezrag, A., Malafronte, N., Bouheroum, M., Travaglino, C., Russo, D., Milella, L., et al. (2017). Phytochemical and antioxidant activity studies on Ononis angustissima L. aerial parts: isolation of two new flavonoids. Nat. Prod. Res. 31, 507-514. doi: 10.1080/14786419.2016.1195381

Mhamdi, B., Abbassi, F., and Abdelly, C. (2015). Chemical composition, antioxidant and antimicrobial activities of the edible medicinal Ononis natrix growing wild in Tunisia. Nat. Prod. Res. 29, 1157-1160. doi: 10.1080/14786419.2014.981188

Mocan, A., Zengin, G., Uysal, A., Gunes, E., Mollica, A., Degirmenci, N. S., et al. (2016). Biological and chemical insights of Morina persica L.: a source of bioactive compounds with multifunctional properties. J. Funct. Foods 25, 94-109. doi: 10.1016/j.jff.2016.05.010

Mükemre, M., Behçet, L., and Çakılcığlu, U. (2015). Ethnobotanical study on medicinal plants in villages of Çatak (Van-Turkey). J. Ethnopharmacol. 166, 361-374. doi: 10.1016/j.jep.2015.03.040

Murugan, R., and Parimelazhagan, T. (2014). Comparative evaluation of different extraction methods for antioxidant and anti-inflammatory properties from Osbeckia parvifolia Arn.-An in vitro approach. J. King Saud Univer. Sci. 26, 267-275. doi: 10.1016/j.jksus.2013.09.006

Nachon, F., Carletti, E., Ronco, C., Trovaslet, M., Nicolet, Y., Jean, L., et al. (2013). Crystal structures of human cholinesterases in complex with huprine $\mathrm{W}$ and tacrine: elements of specificity for anti-Alzheimer's drugs targeting acetyl-and butyryl-cholinesterase. Biochem. J. 453, 393-399. doi: 10.1042/BJ201 30013

Omura, S., and Campbell, W. C. (2015). Nobel Prize for artemisinin brings phytotherapy into the spotlight. Phytomedicine 22, A1-A3. doi: 10.1016/j.phymed.2015.10.003

Orhan, D. D., Özçeli̇k, B., Hoşbaş, S., and Vural, M. (2012). Assessment of antioxidant, antibacterial, antimycobacterial, and antifungal activities of some plants used as folk remedies in Turkey against dermatophytes and yeast-like fungi. Turkish J. Biol. 36, 672-686. doi: 10.3906/biy1203-33

Osakabe, N., Yasuda, A., Natsume, M., and Yoshikawa, T. (2004). Rosmarinic acid inhibits epidermal inflammatory responses: anticarcinogenic effect of Perilla frutescens extract in the murine two-stage skin model. Carcinogenesis 25, 549-557. doi: 10.1093/carcin/bgh034

Otto, M. (2009). Staphylococcus epidermidis-the 'accidental' pathogen. Nat. Rev. Microbiol. 7, 555-567. doi: 10.1038/nrmicro2182

Ozkan, O. E., Zengin, G., Akca, M., Baloglu, M. C., Olgun, C., Altuner, E. M., et al. (2015). DNA protection, antioxidant, antibacterial and enzyme inhibition activities of heartwood and sapwood extracts from juniper and olive woods. RSC Adv. 5, 72950-72958. doi: 10.1039/C5RA12302J

Peña-Cerda, M., Arancibia-Radich, J., Valenzuela-Bustamante, P., PérezArancibia, R., Barriga, A., Seguel, I., et al. (2017). Phenolic composition and antioxidant capacity of Ugni molinae Turcz. leaves of different genotypes. Food Chem. 215, 219-227. doi: 10.1016/j.foodchem.2016.07.159

Pesaresi, A., and Lamba, D. (in press). Torpedo Californica acetylcholinesterase in complex with a tacrine-nicotinamide hybrid inhibitor. Protein Data Bank. doi: $10.2210 / \mathrm{pdb} 4 \mathrm{x} 3 \mathrm{c} / \mathrm{pdb}$

Picot, M., Zengin, G., Mollica, A., Stefanucci, A., Carradori, S., and Mahomoodally, M. (2017). In vitro and in silico studies of mangiferin from Aphloia theiformis on key enzymes linked to diabetes type 2 and associated complications. Med. Chem. 13, 1-8. doi: 10.2174/1573406413666170307163929

Potenza, L., Calcabrini, C., De Bellis, R., Mancini, U., Cucchiarini, L., and Dachà, M. (2008). Effect of quercetin on oxidative nuclear and mitochondrial DNA damage. Biofactors 33, 33-48. doi: 10.1002/biof.5520330104 
Prieto, P., Pineda, M., and Aguilar, M. (1999). Spectrophotometric quantitation of antioxidant capacity through the formation of a phosphomolybdenum complex: specific application to the determination of vitamin E. Anal. Biochem. 269, 337-341. doi: 10.1006/abio.1999.4019

Rice-Evans, C. A., Miller, N. J., and Paganga, G. (1996). Structure-antioxidant activity relationships of flavonoids and phenolic acids. Free Radic. Biol. Med. 20, 933-956. doi: 10.1016/0891-5849(95)02227-9

Ríos, J. L., Francini, F., and Schinella, G. R. (2015). Natural products for the treatment of type 2 diabetes mellitus. Planta Med. 81, 975-994. doi: 10.1055/s-0035-1546131

Roseiro, L. B., Rauter, A. P., and Serralheiro, M. L. M. (2012). Polyphenols as acetylcholinesterase inhibitors: structural specificity and impact on human disease. Nutr. Aging 1, 99-111

Sarikürkcü, C., Cengiz, M., Çomak, Z., Zengin, G., and Aktumsek, A. (2016). İki Ononis Türünün Antioksidan Aktivitelerinin Karşılaştırılması. Süleyman Demirel Üniversitesi Fen Bilimleri Enstitüsü Dergisi 20, 298-302. doi: $10.19113 /$ sdufbed.51573

Sayari, N., Saidi, M. N., Sila, A., Ellouz-Chaabouni, S., and Bougatef, A. (2016). Chemical composition, angiotensin I-converting enzyme (ACE) inhibitory, antioxydant and antimicrobial activities of Ononis natrix leaves extracts. Free Radic. Antioxid. 6:23. doi: 10.5530/fra.2016.1.3

Shelley, J. C., Cholleti, A., Frye, L. L., Greenwood, J. R., Timlin, M. R., and Uchimaya, M. (2007). Epik: a software program for $\mathrm{pK}$ a prediction and protonation state generation for drug-like molecules. J. Comput. Aided Mol. Des. 21, 681-691. doi: 10.1007/s10822-007-9133-z

Shono, T., Ono, M., Izumi, H., Jimi, S. I., Matsushima, K., Okamoto, T., et al. (1996). Involvement of the transcription factor NF- $\mathrm{BB}$ in tubular morphogenesis of human microvascular endothelial cells by oxidative stress. Mol. Cell. Biol. 16, 4231-4239. doi: 10.1128/MCB.16.8.4231

Silva, C. H. T. P. D., Sobrinho, T. J. D. S.P., Lima, D. D. C. A., and Amorim, E. L. C. D. (2011). Antioxidant capacity and phenolic content of Caesalpinia pyramidalis Tul. and Sapium glandulosum (L.) Morong from Northeastern Brazil. Molecules 16, 4728-4739. doi: 10.3390/molecules 16064728

Silva, J. P., Gomes, A. C., and Coutinho, O. P. (2008). Oxidative DNA damage protection and repair by polyphenolic compounds in PC12 cells. Eur. J. Pharmacol. 601, 50-60. doi: 10.1016/j.ejphar.2008.10.046

Slinkard, K., and Singleton, V. L. (1977). Total phenol analysis: automation and comparison with manual methods. Am. J. Enol. Vitic. 28, 49-55.

Sohretoglu, D. (2007). Tedavide Kullanilan Bitkiler. Ononis Spinosa FFD Monograflarıtedavide Kullanılan Bitkiler. Ononis Spinosa FFD Monografları, ed O. Demirezer. Istanbul: Nobel Tip Kitapevi.

Sukumaran, S. T., Girija, S., and Sheela, N. G. (2016). In vitro cytotoxic activity of root methanol extract of Pseudarthria viscida (L.) wight and arn. against hela, hep g2 and 1929 cell lines. Eur. J. Pharm. Med. Res. 3, 498-501.

Süntar, İ., Baldemir, A., Coşkun, M., Keleş, H., and Akkol, E. K. (2011). Wound healing acceleration effect of endemic Ononis species growing in Turkey. J. Ethnopharmacol. 135, 63-70. doi: 10.1016/j.jep.2011.02.023

Tepe, B. (2008). Antioxidant potentials and rosmarinic acid levels of the methanolic extracts of Salvia virgata (Jacq), Salvia staminea (Montbret and Aucher ex Bentham) and Salvia verbenaca (L.) from Turkey. Bioresour. Technol. 99, 1584-1588. doi: 10.1016/j.biortech.2007.04.008

Tundis, R., Loizzo, M., and Menichini, F. (2010). Natural products as $\alpha$ amylase and $\alpha$-glucosidase inhibitors and their hypoglycaemic potential in the treatment of diabetes: an update. Mini Rev. Med. Chem. 10, 315-331. doi: $10.2174 / 138955710791331007$

Uysal, A., Zengin, G., Mollica, A., Gunes, E., Locatelli, M., Yilmaz, T., et al. (2016). Chemical and biological insights on Cotoneaster integerrimus: a new (-)-epicatechin source for food and medicinal applications. Phytomedicine 23, 979-988. doi: 10.1016/j.phymed.2016.06.011

Uysal, S., Zengin, G., Locatelli, M., Bahadori, M. B., Mocan, A., Bellagamba, G., et al. (2017). Cytotoxic and enzyme inhibitory potential of two Potentilla species ( $P$. speciosa L. and $P$. reptans Willd.) and their chemical composition. Front. Pharmacol. 8:290. doi: 10.3389/fphar.2017. 00290

Vattem, D., Jang, H. D., Levin, R., and Shetty, K. (2006). Synergism of cranberry phenolics with ellagic acid and rosmarinic acid for antimutagenic and DNA protection functions. J. Food Biochem. 30, 98-116. doi: $10.1111 / j .1745-4514.2005 .00063 . x$
Wimo, A., and Prince, M. (2010). Alzheimer's Disease International. 2010. World Alzheimer Report.

Wollenweber, E., Dörr, M., Rivera, D., and Roitman, J. N. (2003). Externally accumulated flavonoids in three Mediterranean Ononis species. Zeitschrift fuer Naturforschung C 58, 771-775. doi: 10.1515/znc-2003-11-1202

Wulan, D. R., Utomo, E. P., and Mahdi, C. (2014). Molecular modeling of Ruellia tuberosa L compounds as a-amylase inhibitor: an in silico comparation between human and rat enzyme model. Bioinformation 10, 209-215. doi: 10.6026/97320630010209

Xie, Y., Yang, W., Chen, X., and Xiao, J. (2014). Inhibition of flavonoids on acetylcholine esterase: binding and structure-activity relationship. Food Funct. 5, 2582-2589. doi: 10.1039/C4FO00287C

Yamamoto, K., Miyake, H., Kusunoki, M., and Osaki, S. (2011). Steric hindrance by 2 amino acid residues determines the substrate specificity of isomaltase from Saccharomyces cerevisiae. J. Biosci. Bioeng. 112, 545-550. doi: 10.1016/j.jbiosc.2011.08.016

Yasuda, M., Ohzeki, Y., Shimizu, S., Naito, S., Ohtsuru, A., Yamamoto, T., et al. (1999). Stimulation of in vitro angiogenesis by hydrogen peroxide and the relation with ETS-1 in endothelial cells. Life Sci. 64, 249-258. doi: 10.1016/S0024-3205(98)00560-8

Yerlikaya, A., Erdoǧan, E., Okur, E., Yerlikaya, S., and Savran, B. (2016). A novel combination treatment for breast cancer cells involving BAPTAAM and proteasome inhibitor bortezomib. Oncol. Lett. 12, 323-330. doi: 10.3892/OL.2016.4597

Yin, S.-Y., Yang, N.-S., and Lin, T.-J. (2017). Phytochemicals approach for developing cancer immunotherapeutics. Front. Pharmacol. 8:386. doi: 10.3389/fphar.2017.00386

Yõlmaz, B. S., Özbek, H., Çitoğlu, G. S., Uğraş, S., Bayram, İ., and Erdoğan, E. (2006). Analgesic and hepatotoxic effects of Ononis spinosa L. Phytother. Res. 20, 500-503. doi: 10.1002/ptr.1891

Yousaf, M., Al-Rehaily, A. J., Ahmad, M. S., Mustafa, J., Al-Yahya, M. A., Al-Said, M. S., et al. (2015). A 5-alkylresorcinol and three3, 4dihydroisocoumarins derived from Ononis natrix. Phytochem. Lett. 13, 1-5. doi: 10.1016/j.phytol.2015.05.002

Zeng, L., Zhang, G., Lin, S., and Gong, D. (2016). Inhibitory mechanism of apigenin on $\alpha$-glucosidase and synergy analysis of flavonoids. J. Agric. Food Chem. 64, 6939-6949. doi: 10.1021/acs.jafc.6b02314

Zengin, G. (2016). A study on in vitro enzyme inhibitory properties of Asphodeline anatolica: new sources of natural inhibitors for public health problems. Ind. Crops Prod. 83, 39-43. doi: 10.1016/j.indcrop.2015.12.033

Zengin, G., Ceylan, R., Katanić, J., Mollica, A., Aktumsek, A., Boroja, T., et al. (2017). Combining in vitro, in vivo and in silico approaches to evaluate nutraceutical potentials and chemical fingerprints of Moltkia aurea and Moltkia coerulea. Food Chem. Toxicol. 107(Pt B), 540-553. doi: 10.1016/j.fct.2017.04.004

Zengin, G., Sarikurkcu, C., Aktumsek, A., Ceylan, R., and Ceylan, O. (2014). A comprehensive study on phytochemical characterization of Haplophyllum myrtifolium Boiss. endemic to Turkey and its inhibitory potential against key enzymes involved in Alzheimer, skin diseases and type II diabetes. Ind. Crops Prod. 53, 244-251. doi: 10.1016/j.indcrop.2013.12.043

Zengin, G., Uysal, S., Ceylan, R., and Aktumsek, A. (2015). Phenolic constituent, antioxidative and tyrosinase inhibitory activity of Ornithogalum narbonense L. from Turkey: a phytochemical study. Ind. Crops Prod. 70, 1-6. doi: 10.1016/j.indcrop.2015.03.012

Zhuo, H., Payan, F., and Qian, M. (2004). Crystal structure of the pig pancreatic $\alpha$ amylase complexed with $\rho$-nitrophenyl- $\alpha$-d-maltoside-flexibility in the active site. Protein J. 23, 379-387. doi: 10.1023/B:JOPC.0000039552.94529.95

Conflict of Interest Statement: The authors declare that the research was conducted in the absence of any commercial or financial relationships that could be construed as a potential conflict of interest.

Copyright (c) 2017 Yerlikaya, Zengin, Mollica, Baloglu, Celik Altunoglu and Aktumsek. This is an open-access article distributed under the terms of the Creative Commons Attribution License (CC BY). The use, distribution or reproduction in other forums is permitted, provided the original author(s) or licensor are credited and that the original publication in this journal is cited, in accordance with accepted academic practice. No use, distribution or reproduction is permitted which does not comply with these terms. 